
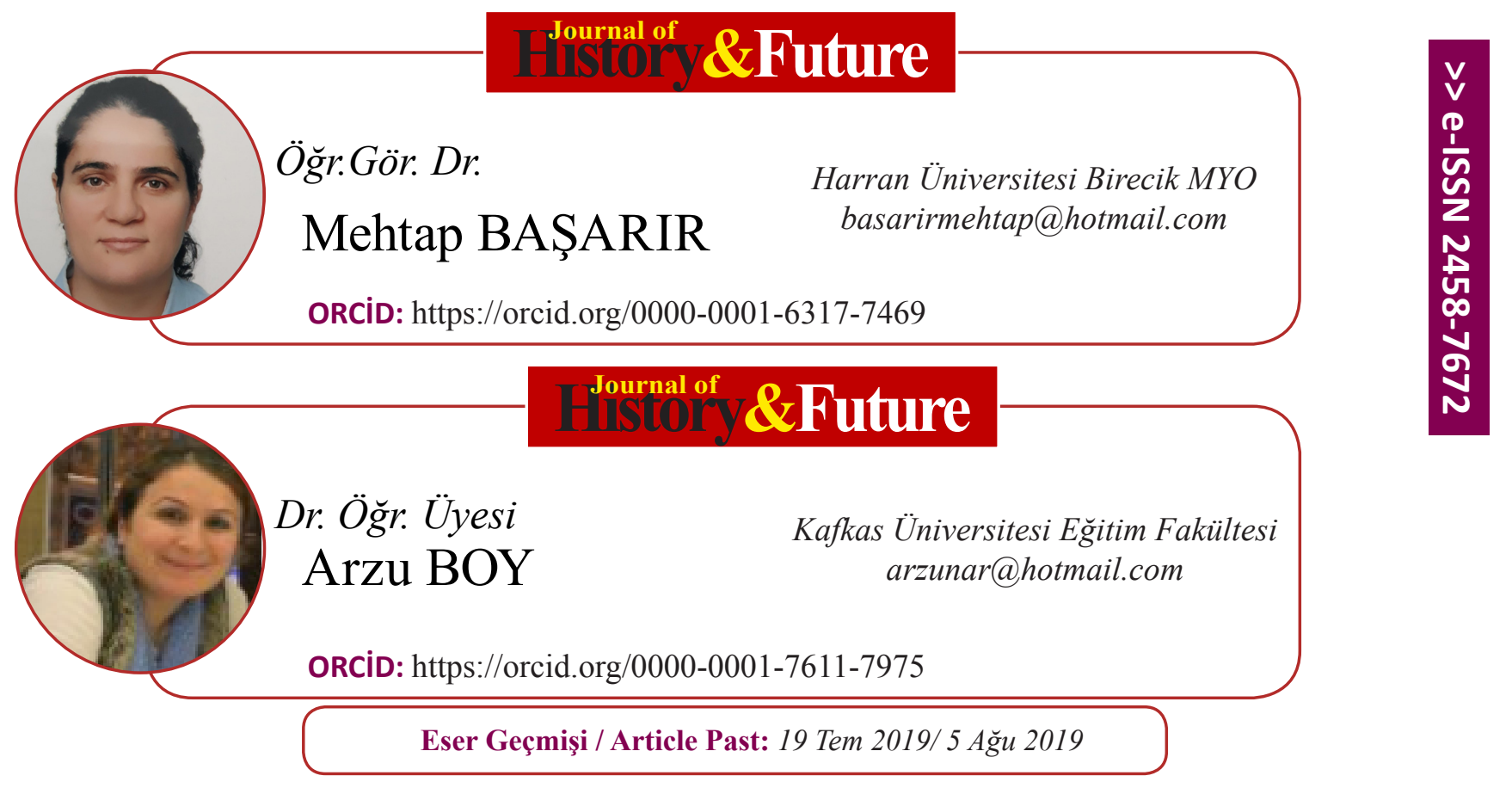

Araştırma Makalesi

DOI: http://dx.doi.org/10.21551/jhf.594479

Research Paper

Orjinal Makale / Orginal Paper

\title{
İkinci Dünya Savaşı Esnasında İsmet İnönü’nün Meclis Konuşmalarının Basındaki Yankıları
}

\author{
Reflections of The Parliament Speech Of The İsmet Inönü in the \\ Press during the Second World War
}

Öz

1914'te başlayan Birinci Dünya Savaşı İtilaf güçlerinin zaferiyle sonuçlanmıştı. Birinci Dünya Savaşı'ndan yenilgi ile çıkan devletler yaralarını sarmaya çalışırken, savaştan zaferle ayrilan İngiltere ve Fransa gibi statükocu devletler, mevcut durumun korunmasından yana bir tavir içerisine girmişlerdir. Birinci Dünya Savaşı'nı Versay gibi yıkıcı bir antlaşma ile sonuçlandıran Almanya ve onun yanında yer alan İtalya'nın izlediği saldırgan politika dünyayı yeni bir savaşın eşiğine getirmişti. Türkiye ise Birinci Dünya Savaşı'nda aldığı yaraları sarmadan, Kurtuluş Savaşı'nda ölüm kalım mücadelesi vermişti. Türkiye, İkinci Dünya Savaşı öncesinde izlediği politika ile yeni kurulan devletin köklerini sağlamlaştırmaya çalışmış ve yeninden bir savaşın tarafı olmak düşüncesi bile ülke için ağır gelmiştir.

Savaş süresince Türkiye'nin yönetiminde bulunanlar, savaşı görmüş ve tecrübe edinmiş kişilerdi. Özellikle İsmet İnönü, tecrübelerine dayanarak ülkeyi savaşın dışında tutmayı kendine ilke edinmiştir. 1939-1945 yılları boyunca İnönü'nün düşünceleri, yaptığı meclis konuşmalarına yansımıştır. 1939'da yaptığı açılış konuşmasında, amacının savaşın ilerlemesine engellemek olduğu ve harbin son bulmasını umut ettiğini dile getirmiştir. 1939-1942 döneminde savaş dışı kalma ko- 
nusunu konuşmalarında dile getirmiş, 1943'teki açılış konuşmasında ise Türkiye'nin savaş dışında kalmasına rağmen savaşın zararlı etkilerini hissettiğini dile getiren İnönü’nün, 1944'te yaptığı konuşmada müttefikler lehine olumlu ifadeler kullandığı görülmüştür. 1945'te yaptığı konuşmada; Türk topraklarında kimsenin hakkının olmadığı ve şerefli insanlar olarak yaşamaya devam edeceklerini izah etmiştir.

İnönü’nün yaptığı konuşmalar Türk ve yabancı basında geniş yankı uyandırmış, konuşmalarıyla ilgili makaleler kaleme alınmıştır. Çalışmada, İnönü’nün konuşmaları ile ilgili basında, mevcut olan her ince ayrıntıya yer verilmiş ve okuyucuya aktarılmaya çalışılııştır. Araştırma esnasında konu ile ilgili kaynak taraması yapılmış ve basındaki bilgilerle harmanlanmıştır.

Anahtar Kelimeler: İkinci Dünya Savaşı, İsmet İnönü, Meclis, İngiltere, Almanya, Fransa

\begin{abstract}
World War I, which starter in 1914, resulted in the victory of the allied powers. While the states that emerged with a defeat from World War I tried to heal their wounds, the status quo supporter states such as England and France, who left the war with victory, took a stand in favor of the preservation of the current situation. The aggressive policy of Germany who ended the World War I with a destructive treaty such as Versailles, and Italy who took side with it brought the world to the brink of a new war. And, in the World War I, Turkey struggled for life and death in the War of Independence without healing its wounds. Turkey tried to consolidate the roots of the newly established state with his policy before World War II, and even the idea of being a party to a new war was too hard for the country.

People who governed Turkey during the war saw it and gained experience about the war. İsmet İnönü, in particular, based on his experience, kept the country out of war as a principle. During the years of 1939-1945, İnönü's thoughts were reflected in his parliamentary speeches. And in his opening speech in 1939, he said that his purpose was to prevent progress of war and hoped the end of war. 1939-1942 period, he has voiced in the speeches of the irrelevance of war, while in 1943 the opening speech, İnönü who said that, although Turkey remained out of the war, he felt the harmful effects of war and in his speech in 1944 his positive expressions were seen in favor of the allies. In his speech in 1945; He explained that no one has the right to live on Turkish territory and that they will continue to live as honorable people.

İnönü's speeches have had a wide impact in the Turkish and foreign press, and articles about his speeches have been written. In this study, every fine detail that is available in the press about İnönü's speeches has been included and tried to be conveyed to the reader. During the study, the relevant literature was reviewed and blended with the information in the press.
\end{abstract}

Keywords: World War Second, İsmet İnönü, Parliament, England, Germany, France 


\section{Giriș}

1

919-1923 yılları arasında Anadolu'da büyük bir kurtuluş mücadelesi gerçekleşmesinin akabinde, Lozan Antlaşması ile Türkiye Cumhuriyeti'nin temelleri atılmıştı. 'Türkiye Cumhuriyeti'nin dış politikasının esası "yurtta sulh cihanda sulh” politikasına dayandırılmıştır. Öyle ki Mili Mücadele'de Anadolu'ya büyük tahribat vermiş olan Yunanistan'la bile 1930'da Dostluk ve Kardeşlik Antlaşması yapılmıştı. ${ }^{2}$ Bu bağlamda 1923-38 arası dönemde Türkiye, dışarda dostane ilişkiler yürüterek politikasını bu temele oturtmaya çalışmıştır. İkinci Dünya Savaşı’nın ayak seslerinin gelişinden savaşın bittiği ana kadar mümkün mertebe devleti savaştan uzak tutmak konusunda çaba sarf edilmiştir. Çünkü yeni kurulan devletin savaştan uzak tutulması devletin menfaatineydi. İkinci Dünya Savaşı esnasında başta İsmet İnönü olmak üzere devleti yönetenler savaşı gören ve savaşın kokusunu duyan kişilerdi. Savaşın neler getirebileceğini önceden sezebilen tecrübe edilmiş nitelikleri vard $1 .{ }^{3}$ İsmet İnönü’nün savaştan uzak duran ihtiyatı halleri bazı büyük devletler tarafından çekingenlik olarak yorumlanmış olsa da savaşın bitiminden şu ana kadar ki süreç zarfında Türkiye'nin menfaati açısından en doğru karar olduğu aşikârdır. İnönü'nün politikası Türkiye'nin toprak bütünlügünü koruma olarak tanımlanabilir. Bu tanım "Ne başkasının bir karış toprağında gözümüz var. Ne de başkasına bir karış toprak veririz” şeklinde değerlendirilebilir. ${ }^{4}$

Türkiye'yi savaş dış1 tutmaya çalışan İnönü, savaşla ilgili düşüncelerini şu şekilde belirtmiştir: "Kendi emniyetimiz ve müşterek sulh ve emniyet idealini takviye edecek taahhütlerden çekinmeyeceğiz. Komşularımıza gelecek tehlikeleri, bir adım sonra bize gelecek gibi önlemek için iktidarımızda olan tedbirleri alacağı."'5 Burada, İnönü Türkiye'nin emniyeti ve sulhu için bir takım anlaşmalar yapılabileceğinden bahsetmiş ve komşudaki tehlikenin Türkiye'ye gelmemesi için her türlü tedbirin alınacağının sinyallerini vermiştir. Türkiye'nin savaş süresince yaptığı bütün antlaşmaların temelinde toprak bütünlüğünü koruma ve savaşın dışında kalma isteği mevcuttur.

Almanya'nın Polonya'yı işgal etmesi ve İngiltere'nin Almanya'ya savaş açması üzerine İkinci Dünya savaşı başlamıştı. ${ }^{6}$ Savaşın ayak sesleri etrafinda gelişen olaylar zincirinde; Almanya'nın İtalya'yla ittifakı ve İtalyan'ın Nisan 1939`da Arnavutluk'u istila etmesi, Balkanlar'da ki ve buna ek olarak Akdeniz'de ki çekişmeler Türkiye için potansiyel bir tehdidi işaret etti. Buradan hareketle Başbakan Refik Saydam mecliste yaptığı konuşmasında, Türkiye'nin dış politikasını mümkün olduğunca "tam tarafsızlık" biçiminde tanımlamıştır. Ancak yukarıda zikrettiğimiz uluslararası karışıklıklar karşısında yer alan Türkiye, Balkan ve Akdeniz bölgeleri istikrarsızlaşırken kendi güvenliğini tehlikeye atmadan tarafsız kalamayacağının farkına varmıştır. Böylece denge sağlamak maksadıyla hareket eden Türkiye, ${ }^{7} 19$ Ekim 1939'da İngiltere ve Fransa ile Karşılıklı Yardım Antlaşması'nı imzaladı. Bu durumda Türkiye, Avrupa'daki savaşta anti-revizyonist devletlerle işbirliği yapmayı prensip itibariyle kabul etmiştir. ${ }^{8}$ Öte taraftan Almanya sürekli olarak Türkiye'yi kendi yanında savaşa sokma çabası göstermesine rağmen Türkiye bunu kabul etmemiş9 fakat Almanya'nın Fransa'yı tam olarak işgal etmesi üzerine Almanya ile ilişkilerini düzeltme isteği duymuş ve 18 Haziran 1941'de Türk-Alman Saldırmazlık Paktı

1 Cemil Bilsel, Lozan, Sosyal Yayınlar, İstanbul 1998, s.1.

2 İsmail Soysal, Türkiye'nin Siyasal Andlaşmaları, TTK Yayınları, Ankara 2000, s. 399.

3 Şevket Süreyya Aydemir, II. Adam, C.II, Remzi Kitabevi, İstanbul 2005, s.137.

4 Edward Weisband, İkinci Dünya Savaşı’nda İnönü’nün Dış Politikası I, Çev: M. Ali Kayabal, Cumhuriyet Yayınları, İstanbul 2000, s. 21-28.

5 Ahmet İlyas, Orhan Turan, İnönü Dönemi Türk Dış Politikası, Atatürk İlkeleri ve İnkılap Tarihi Enstitüsü Atatürk Dergisi, 20121 (1), ss. 319-341.

6 Fahir Armaoğlu, 20 Yüzyıl Siyasi Tarihi 1914-1995, Timaş, İstanbul 2006, s. 361.

7 John M. VanderLippe, Politics of Turkish Democracy: Ismet Inönü and Formation of the Multi-Party System 1938-1950, State of New York Press, USA 2005, s. 42-43.

8 Mehmet Gönlübol, Cem Sar, Atatürk ve Türkiye'nin Dış Politikası (1919-1938), Atatürk Araştırma Merkezi Yayınları, Ankara 2013, s. 138.

9 William Hale, Türk Dış Politikası 1774-2000, Arkeoloji ve Sanat Yayınları, İstanbul 2003, s. 62. 
yapılmıştır. ${ }^{10}$ Savaş süresince savaşın dışında kalmaya çalışan Türkiye, Almanların Rusya'ya karşı yenilgi aldığı Stalingrad Savaşı'ndan sonra zarar görmemek adına Müttefiklere yaklaşma çabası göstermiş fakat savaşa birebir dâhil olmak istememiştir. ${ }^{11}$ Bundan sonraki süreçte Almanya, özellikle Türkiye'nin tarafsız kalmasını, Müttefikler ise kendi yanlarında savaşa girmesini istemiş ve 12-24 Ocak 1943'te Kazablanka'da başlanarak 4-6 Aralık 1943'te Kahire'de Churchill, Roosevelt ve İnönü arasında yapılan görüşmelere kadar sürekli olarak Türkiye'ye savaşa girmesi konusunda baskı uygulamışlardır. ${ }^{12}$ Türkiye, savaşın sonlarına doğru gelişen olaylardan dolayı Müttefiklere yaklaşmak zorunda kalmış fakat fiiliyatta savaşa hiçbir zaman katılmamıştır. İsmet İnönü başlangıçtan beri uygulamaya çalıştığı Türkiye'nin toprak bütünlügünü koruma konusunda başarı sağlamıştır. ${ }^{13}$ Bu bağlamda İnönü, 1939'dan 1945'e kadar süreçteki 1 Kasım nutuklarında Türkiye'nin dış politikası ile düşüncelerini dile getirmiş ve bu nutuklar basındaki yerini almıştır. 1924 Anayasası'ndan itibaren 1961 Anayasası'na kadar cumhurbaşkanları, her yıl kasım ayının birinci günü TBMM'de gerçekleştirdikleri nutuklarla meclisin yeni yasama yılını açmıştır. Türkiye Cumhuriyeti, anayasal bir devlettir. Yasama, yürütme ve yargı organları görev ve yetkilerini anayasadan almaktadır. Buradan hareketle anayasal olarak cumhurbaşkanı devletin başıdır. Türkiye Cumhuriyeti'nin ilk cumhurbaşkanı seçilen Mustafa Kemal Atatürk, seçildiği 29 Ekim 1923 tarihinden başlayarak, vefat ettiği 10 Kasım 1938 tarihine kadar aralıksız on beş yıl bu görevi yürütmüştür. Atatürk, aynı zamanda Türkiye Cumhuriyeti'nin en uzun süre görev yapan cumhurbaşkanıdır. Atatürk’ten sonra seçilen İsmet İnönü ise on iki yıl süreyle cumhurbaşkanlığı görevini yürütmüştür.1924 Anayasası'nda cumhurbaşkanının görev süresi seçim dönemi ile sınırlandırılmıştır. Yine 1924 Anayasası'nda öngörülen cumhurbaşkanının yasama yılı başında TBMM'de açılış konuşması yapma ve törenli oturumlarda TBMM'ye başkanlık etme yetkileri söz konusudur. ${ }^{14}$ Bu bağlamda TBMM her yıl kasımın birinci günü cumhurbaşkanının bir nutku ile açılmıştır. Bu nutuk hükümetin bir sene içinde yaptıklarının bir özeti, devletin içinde bulunduğu iç ve dış durumun kısa ve toplu anlatımı, gelecek seneyle ilgili başlıca yeni işlerin ilk habercisidir. Hükümetin, devlet reisi tarafından meclise sunulmuş bir bilançosu mahiyetinde ve temel unsurları bakanlıklar tarafından hazırlanması zarurî olan, bu nutuk, özellikle İkinci Dünya Savaşı ortamında, İsmet İnönü'nün üslûp ve şahsiyeti damgası altında, ahvale ve şartlara göre büyük bir önem kazanmıştır. ${ }^{15}$ Soysal'a göre ise İnönü’nün 1 Kasım nutukları, gelecek yıl içinde meclis grubundaki tartışmalara 1şık tutan bir kılavuz niteliğindedir. ${ }^{16} \mathrm{Bu}$ nedenle savaş ortamında dikkat çeken İnönü’nün 1 Kasım nutukları, cumhuriyet Türkiye'sinin adeta kısa tarihi niteliğindedir. Buradan hareketle çalışmamızda, 1 Kasım nutuklarına odaklanılacaktır. Bu odaklanma ile konuşmalarda vurgulanan politikalar çerçevesinde, çalışmamızın konusunu teşkil eden İkinci Dünya Savaşı'nda Türkiye'nin izlediği stratejilerin iz düşümlerine bakılacaktır.

10 Ahmet Şükrü Esmer, Oral Sander, Olaylarla Türk Dış Politikası (1919-1945), Siyasal Kitabevi, Ankara 1996, s. 157.

11 Sevda Mutlu, Devlet Adamı Kimliği İle İsmet İn̈nü’nün Düşünce ve Uygulamalarının Değerlendirilmesi, (Basılmamış Doktora Tezi), Cumhuriyet Üniversitesi Sosyal Bilimler Enstitüsü, Sivas 2007, s. 218.

12 Rifat Uçarol, Siyasi Tarih (1789-2014), Der Yayınları, İstanbul 2015, s. 912-915.

13 Caner Erdoğan, “Tek Parti Dönemi’nde Cumhuriyet Halk Partisinin İdeolojik Değişim ve Dönüşüm Sürecinin Çözümlenmesi”, Uluslararası Sosyal Araştırmalar Dergisi, Say1:51, Ağustos 2017, ss.270279.

14 Tarihe Düşülen Notlar-1, Yasama Yılı Açıllıslarında Cumhurbaşkanlarının Konuşmaları-1 (1 Mart 192414 Aralık 1987), TBMM Yayınlar1, Ankara 2011.

15 Necmeddin Sadak, "Emniyet Havası İçinde İnsanlara Temiz Nefes Aldıracak Bir Adalet Nizamı İstiyoruz", Akşam, 2 Kasım 1943, s. 1.

16 Weisband, İkinci Dünya Savaşı'nda İnönü’nün Dış Politikası I, s. 51. 


\subsection{9-1942 Arası Dönem}

\subsection{Türkiye - Müttefik Devletler İlişkileri}

Dünyayı yeni bir savaşa götüren olaylar 1939'da hızlı bir şekilde gelişim göstermiş, merkezi devletler, Mihver ve Müttefik olmak üzere iki kısma ayrılmıştı. Mihver Devletleri'ni Almanya, İtalya ve Japonya, Müttefik Devletleri'ni ise Fransa, İngiltere ve SSCB oluşturmuş̧tur. ${ }^{17}$ İki taraf arasında başlayan mücadelede Türkiye, barış yanlısı bir politika takip etmiş olmasına rağmen 16 Ekim 1939'da Türkiye ve Rusya arasında yapılan görüşmelerde, Rusya'nın, Boğazlardaki geçiş statüsünün kendi lehine değiştirilmesi ve Boğazlar üzerinde Türkiye ile birlikte söz ve kontrol hakkı konularında ortaklık kurma taleplerinde bulunması üzerine iki devlet arasında antlaşma mümkün olmamıştı. Bu durum Türkiye'yi, Fransa ve İngiltere'ye yaklaştırmış, üç devlet arasında 19 Ekim 1939'da Karşı1ıklı Yardım Antlaşması yapılmıştır. ${ }^{18}$

Dünya siyasetindeki bu gelişim ve değişim, İnönü’nün 1 Kasım 1939'da yaptığı açılış konuşmasına yans1mıştır. İnönü, TBMM'nin yaptığı açılış konuşmasında geçen yılın huzur ve emniyet içerisinde geçtiğini, fikirde ve cemiyette asayişin olduğunu belirtmiştir. Dış siyasetin hızlı bir gelişim gösterdiğini, Avrupa buhranının dünya savaşına dönüştüğ̈nü, Türkiye'nin bu ortamda kendi emniyetini temin etme gayreti ile beraber barıştan yana bir politika takip ettiğini dile getirmiştir. 12 Mayıs'ta İngiltere ve 23 Haziran'da Fransa ile yapılan beyannamelerin bu gayretin mahsulü olduğunu izah etmiştir. Ayrıca İnönü, konuşmasında, 19 Ekim'de yapılan antlaşmanın hiçbir devletin aleyhinde olmadığını ve Türkiye'nin uluslararası sulh ve emniyete hizmet ederek emniyetini sağlamaya çalıştığını, amacının savaşın daha fazla dağılmasını engellemek olduğunu söyleyerek, harbin kısa sürmesini umut ettiğini ilave etmiştir. ${ }^{19}$ Türkiye'yi harp mıntıkası haricinde bırakmayı vazife edindiğini de sözlerine ekleyen İnönü, aslında bu cümlesi ile savaş sürecinde takip ettiği politikayı da özetlemiştir. İnönü, savaşın başlangıcından sonuna kadar yaptığı konuşmalarda, Türkiye'nin iç ve dış siyasetinden bahsetmiş ve Türk ve yabancı basın bu konuşmalara oldukça büyük bir önem vermiştir.

Falih Rıfkı Atay “Cumhurreisimizin Nutku” başlıklı yazısında, gerek devlet başkanının gerekse cumhuriyet hükümetinin barışa hizmet ettiğini belirtmiş, mayıs ve haziran beyannameleri ile ekimde İngiltere ve Fransa ile yapılan ittifak antlaşmasının uluslararası konjektörde barış ve emniyete hizmet etmiş olduğunu, bu bağlamda emniyet ve taahhütlerini yerine getirecek olan Türkiye'nin de güvenliğe katkı sağlayacağını belirtmiştir. ${ }^{20}$

Akşam gazetesinde ise, "Reisicümhurun Nutku" isimli başmakalesinde Necmeddin Sadak, İnönü’nün uluslararası durumun vahameti karşısında samimi bir şekilde barışı öne çıkardığını vurgulamıştır. Avrupa'da başlayan ve nereye varacağı bilinmeyen savaş karşısında barışa hizmet eden Türkiye'nin kendi gücüne dayanarak ilk olarak kendi emniyetini sağlayacağı, yine bu noktada Türkiye'nin Fransa ve İngiltere ile imzaladığ

17 Refik Turan ve Diğerleri, Atatürk İlkeleri ve İnklap Tarihi, Okutman Yayıncılık, Ankara 2009, s. 278.

18 Antlaşmanın amacı saldırıya karşı koymak için Türkiye, İngiltere ve Fransa arasında gerektiğinde karşılıklı yardım ve destek sağlamaktı. Türkiye’ye bir Avrupa devleti saldırırsa, İngiltere ve Fransa Türkiye'ye her türlü yardımı yapacaktı. İngiltere ve Fransa bir Avrupa devletinin saldırısına uğrarsa ve savaş Akdeniz'e intikal ederse, Türkiye bu iki devlete yardım edecekti. Savaş Avrupa'da olursa; Türkiye, İngiltere ve Fransa yararına tarafsızlık politikasını izleyecekti. İngiltere ve Fransa Yunanistan ve Romanya'ya verdikleri garantilerin yerine getirilmesi için savaşa girerlerse, Türkiye'de bunlara katılacak ve yardım edecekti. Taraflar bu antlaşmanın uygulaması sonucu olarak savaşa girerlerse mütareke ya da barış için birlikte karar vereceklerdi. Antlaşmanın yürürlük süresi on beş yıl olacaktı. Bu maddelerin dışında iki numaralı protokol şu şekildedir: Yukarıda adı geçen antlaşma uyarınca Türkiye tarafından üstlenilmiş olan yükümlülükler, bu ülkenin Sovyetler Birliği ile silahlı bir anlaşmazlığa sürüklenmesine neden olacak ya da böyle bir sonucu verecek bir eyleme onu zorlamayacaktır. ( Uçarol, a.g.e, s. 897-898).

19 Tarihe Düşülen Notlar-1, Yasama Yllı Açıllı̧larında Cumhurbaşkanlarının Konuşmaları-1 (1 Mart 192414 Aralık 1987), TBMM Yayınları, Ankara 2011,s. 102.

20 Falih Rifk1 Atay, "Cumhurreisimizin Nutku”, Ulus, 2 Kasım 1939, s. 2. 
anlaşmanın da barışa hizmet ettiğini belirtmiştir. Yine Sadak, giriştiği bu barış hareketi karşısında dostluklarına vefakâr olan Türkiye'nin barışı genişletmek ve yine barışa hizmet etmek hususunda daima çalışacağını fakat bu barış adına gayretleri sonuç vermezse, cumhuriyet ordularının emir aldıkları vakit üzerlerine düşen vazifeyi yerine getireceğini de ifade etmiştir. ${ }^{21}$

Türkiye, İngiltere ve Fransa ile yaptığı antlaşmada Alman ve İtalyan saldırısı karşısında kendini korumaya almış ve adı geçen devletlerin bir devletin Türkiye'ye saldırması halinde her türlü yardım ve desteği vereceklerini açıklamış olmalarına rağmen, Türkiye, savaştan mümkün mertebe uzak durmuştur. ${ }^{22}$ Tan gazetesinde yazan M. Zekeriya Sertel “Dünya Siyasetinde Türkiye'nin Vaziyeti” başlıklı başmakalesinde dünyayı istila tehlikesine götüren bu yangın karşısında, İnönü’nün Türkiye'nin durumunu açık ve net bir biçimde ortaya sererek Türk milletini rahatlattığı ifade etmiştir. Türkiye'yi harbin dışında tutmak için Türkiye'nin hareket hattının önceden anlaşılır olmasının barış için faydalı olduğunu söyleyerek nutku değerlendiren Sertel, bu noktada barışı sağlayacağına inanan Türkiye'nin, İngiltere ve Fransa ile bir ittifak yaptığının üzerinde durmuştur. "Türkiye'nin bu ittifakla Avrupa'da emniyet mıntıkası oluşturacağı” şeklindeki İnönü’nün sözlerini Sertel, Türkiye'nin geleceğe emniyetle bakabilmesinin ve savaştan mümkün olduğunca uzak kalabilmesinin garantisi şeklinde değerlendirmiştir. Yine Sertel, İnönü’nün nutkunun halka huzur ve emniyet verdiğini söylemekten de geri durmamıştır. ${ }^{23}$

Sertel, İngiltere ile yapılan ittifak antlaşması gereğince “Akdeniz'de statükoyu ihlal eden herhangi bir durum karşısında iki müttefik devlet durumu ele alır birbirlerine danışırlar” biçimindeki anlaşma maddesinden yola çıkarak İtalya'nın savaşa dâhil olmasıyla, iki tarafın durumu değerlendirmesinin Türkiye'nin savaşa dâhil olacağı anlamına gelmediğini vurgulamıştır. Aksine Türkiye'nin bugünkü savaş dışı durumunun hem Müttefiklere hem de Akdeniz statükosuna yardım ettiğini belirterek, İnönü’nün "İngiltere ile en zor şartlar altında dahi ittifak bağlarımız sağlamdır ve sarsılmayacaktır." şeklindeki sözleriyle başmakalesine son vermiştir. ${ }^{24}$

Tan gazetesi 2 Kasım sayısında, "Milli Şefimizin Tarihi Nutku" başlı̆̆ıyla haberi manşetine taşımış ve İnönü’nün söylevinden: "Büyük Meclis ve Türk milleti emin olabilir ki, Cumhuriyet orduları emir aldıkları zaman vazifelerini hakkıyla ifa edeceklerdir." sözlerine dikkat çekmiştir. Diğer gazetelerden farklı olarak İnönü'nün yeni paktın hedefleri üzerinde ehemmiyetle durduğu şeklinde yorumun altında nutuktan bu konuyla alakalı "Bugün olduğu gibi yarın da memleketimizi harp mıntıkası haricinde bırakmayı, emniyet ve taahhütlerimizi ihlal etmemek şartıyla milletimize karşı vazife icabı olarak cidden arzu ediyoruz.” biçiminde İnönü’nün sözlerini haberine taşımıştır. ${ }^{25}$ Haberde, Türkiye'nin emniyetini temin etmek şartı ile savaş dışında kalmayı sağlamaya çalıştı̆̆ı ifade edilmiş, 1939'da İngiltere ve Fransa ile yapılan 19 Ekim 1939'da imzalanan üçlü ittifak anlaşmasına atıf yapılmıştır. Özellikle bu antlaşmanın ikinci protokolünden kaynaklı yükümlülükler, Türkiye'yi Sovyetler Birliği ile bir çatışma ya da anlaşmazlığa asla sürüklemeyecekti. ${ }^{26}$ Sovyet çekincesi ile ilgili madde Türkiye'nin bir taraftan savaş dışı kalmaya çalışmış olmasının bir taraftan da kendini güvenceye almış olmasının belirtisidir.

Akşam gazetesi Milli Şefin nutkunu, 3 Kasım 1940 tarihi itibariyle Milli Şefin mühim nutku başlığıyla manşetine almıştır. Haberde ön plana çıkarılan İnönü'nün sözleri şunlardır: "Milli birlik her zamandan ziyade sağlamdır, icap ederse milletçe her fedakârlığı göze almak hepimizin kati kararıdır. Sovyet Rusya ile münasebatımız dostane mahiyetini tekrar elde etmiştir. İngiltere ile olan ittifak bağlarımızın sağlam ve sarsılmaz olduğunu söylemek benim için bir borçtur. Cumhuriyet ordusunun vazifesini hakkı ile başarabilecek bir ehliyette bulun-

21 Necmeddin Sadak, "Reisicümhurun Nutku”, Akşam, 2 Aralık 1939, s. 1, 8.

22 Wayne Bowen, "Türkiye ve İkinci Dünya Savaşı: "Taraflı Fakat Savaşmayan Ülke”, Türkler, Edt: Hasan Celal Güzel, Kemal Çiçek, Salim Koca, Yeni Türkiye Yayınları, Ankara 2014, ss. 803-812

23 M. Zekeriya Sertel “Dünya Siyasetinde Türkiye’nin Vaziyeti”, Tan, 3 Kasım 1939, s. 1, 6.

24 M. Zekeriya Sertel “İtalya-Yunan Harbi Önünde Türkiye’nin Vaziyeti”, Tan, ,4 Kasım 1940, s. 1-2.

25 “Milli Şefimizin Tarihi Nutku”, Tan, 2 Kasım 1939, s. 1.

26 Cemil Koçak, Türkiye’de Milli Şef Dönemi (1938-1945), C. I, İletişim Yayınları, İstanbul 2015, s. 281. 
duğuna emin olabiliriz." ${ }^{27}$ İnönü konuşmasında İngiltere ile dostluk bağlarının kuvvetli olduğunu dile getirmiştir. Savaş sürecinde ilişkiler iyi tutulmaya çalışılmış hem de savaş dışı nasıl kalınır bunun çabası verilmiştir. Buradan hareketle savaş esnasında aradaki ittifak antlaşmasına dayalı olarak İngiltere, Türkiye' den birçok defa kendi safında yer almasını istemiş, Türkiye ise savaşa girmeden dostane ilişkileri devam ettirmeye çalışmıştır. Türkiye'nin savaş dışı durumu ile ilgili olarak İnönü, Türkiye'nin İngiltere ile bir pakt imzaladığını, kendi güvenliğini İngiltere'nin garantisi altında gördüğünü, fakat bu paktın Fransa'nın çöküşü ile artık uygulanamayacağını belirtmiş ve İngiltere ise Türkiye'nin savaş dışı durumunu kabul etmek zorunda kalmıştır. ${ }^{28}$

Almanya 1940 Nisan'ında Norveç ve Danimarka’ya saldırdığı zaman İngiltere ve Fransa, Balkan ülkeleri arasında bir birliktelik oluşturmak için çeşitli girişimlerde bulunmuştu. Bu bağlamda İngiltere 15 Nisan 1940'da Türk Dışişleri Bakanlığı'na, İtalya'nın Yugoslavya'ya saldırması durumunda takip edeceği politikayı tespit için görüşme talebinde bulunmuştur. 24 Nisan'da verdiği cevapta Yugoslavya'nın toprak bütünlüğüne kayıtsız kalamayacağını fakat Almanya ile savaş devam ederken İtalya'ya savaş ilan edilirse bu iki ülkenin birleşmesinden çekindiğini söylemiştir. 29 Nisan'da İngiltere bu ihtimali görüşmek için üç ülke genelkurmay bakanlarının toplanmasını teklif etmiştir. Türkiye ise bağlayıcı bir karar alınmaması şartıyla görüşmeyi kabul etmiştir. ${ }^{29} \mathrm{Bu}$ görüşmeler dış basına yansımıştır. Berlin basını, İsmet İnönü’nün nutkunun Balkan memleketlerinde çok büyük bir alâka uyandırdığı belirtmiştir. Bu doğrultuda, Belgrad'dan gelen haberler, Yugoslav siyasi ve diplomatik yetkililerinin, İnönü'nün beyanatını, harp harici kalmak için Türkiye'nin elinden geleni yaptığı ve mukadderatını İngilizler ile sıkı bir suretle bağlamak istemediği biçiminde değerlendirmiştir ${ }^{30}$. 29 Nisan'da İngiltere'nin görüşme teklifine, Türkiye'nin bağlayıcı bir karar alınmaması şartıyla görüşmeyi kabul etmesi Balkan basınında görüldüğü üzere İngiltere’ye fazla yaklaşmak istememesi şeklinde değerlendirilmiştir.

İngiltere ve Fransa, 16 Mayıs 1940'da Almanya, Fransa ve Balkanlara karşı saldırıya geçince Ankara'daki Yugoslavya elçisi ile temasa geçmiş, elçi Almanya ve İtalya saldırısına uğramaları durumunda Balkan ülkelerinin ne yapacağını merak etmiştir. İngiltere ve Fransa, İtalya'nın savaşa girmesi durumunda Türkiye'den seferberlik ilan etmesini, aynı şekilde Balkan ülkelerini de teşvik etmesini istemişlerdir. Akabinde İtalya, Fransız cephesindeki savaşlarda başarılı olamamış, Yunanistan'a bir ültimatom vermiş ve stratejik bir noktayı işgal etme hakkını istemiştir. Yunanistan bu teklifi reddetmiş ve ardından İtalya, Yunanistan'ı işgal etmiştir. Türkiye'nin bu durum karşısında Balkan Paktı çerçevesinde Yunanistan'a yardım etme gibi bir yükümlülüğü yoktu. İnönü mecliste yaptığı konuşmasında bu durumla ilgili şu şekilde açıklama yapmıştır. "Son zamanlarda harp harekâtı bazı yeni vesilelerle dikkate şayan inkişaflar gösterdi. Sükûn ve selâmeti bizim için çok ehemmiyetli olan emniyet sahamızın içinde dostumuz ve komşumuz Yunanistan maalesef bu gün harbe sürüklenmiş bulunuyor. Bundan doğan vaziyeti, müttefikimiz İngiltere Hükûmeti ile müştereken tetkik ve mütalaa etmekteyiz." ${ }^{31}$ Yunanistan Başbakanı Metaksas 1940 Şubat'ında, Yunanistan'ın Türkiye ile yalnız Balkan Paktı çerçevesinde karşılıklı yükümlülüğü bulunduğunu, bunun İtalya'ya karşı bir yükümlülük olmadığını açıklamıştı ${ }^{32}$. Öte yandan İnönü, geçen seneden beri ülkenin siyasetinde bir değişiklik olmadığını dile getirdiği konuşmasına şu şekilde devam etmiştir: "Siyasetimiz, siyasî istiklâl ve mülkî tamamiyetimizin mahfuziyetini esas tutmakta ve hâdiselerin seyrine göre tahavvül eden haris emeller ile alâkadar bulunmamaktadır." ${ }^{33}$ İnönü’nün mecliste yaptığı konuşma basında

27 “Şefin Mühim Nutku”, Akşam, 3 Kasım 1940, s.1

28 Osman Akandere, Milli Şef Dönemi, İz Yayıncılık, İstanbul 1998, s. 276.

29 Kahraman Gürbüz, “İkinci Dünya Savaşı'nda Balkanlardaki Gelişmeler ve Türkiye'nin Tutumu”, U.Ü.Fen-Edebiyat Fakültesi Sosyal Bilimler Dergisi, say1:18, 2007/2,ss.363-372.

30 "Reisicumhurun Nutkunun Akisleri”, Akşam, 4 Kasım 1940, s.1.

31 Tarihe Düşülen Notlar-1, Yasama Yılı Açılışlarında Cumhurbaşkanlarının Konuşmaları-1 (1 Mart 192414 Aralı 1987), TBMM Yayınları, Ankara 2011,s.111.

32 Gürbüz, a.g.m. ss.363-372.

33 Tarihe Düşülen Notlar-1, Yasama Yılı Açılışlarında Cumhurbaşkanlarının Konuşmaları-1 (1 Mart 192414 Aralık 1987), TBMM Yayınlar1, Ankara 2011, s.112. 
yankılarını bulmuştur.

Tan gazetesi, İnönü'nün nutkunun özellikle Londra'da çok iyi karşılandığını öne çıkarmaktadır. Bu bağlamda Londra Türkiye'nin durumunu: “Türkiye Boğazların Muhafızı ve Yakın Şark’ın kalkanıdır” biçiminde yorumlamıştır. Reuter'in diplomatik muhabirinin demecine dayanarak verdiği haberinde Tan, İnönü'nün nutkunun İngiltere tarafından iyi karşılandığını belirtmiştir. Buradan hareketle, müttefik Türkiye'nin tecavüzcü kuvvetlere karş1 gerekirse mukavemet edeceği yönündeki duruşuna İngiltere'nin güvendiği belirtilerek, İnönü’nün nutkunun İngiltere ile yapılan anlaşmanın açık ve seçik belirtisi olduğu açıklanmıştır. Ayrıca savaşın Balkanlara indiği bir dönemde bu nutkun yapılmasının manidar olduğu da belirtilse de Yunanistan'ın durumu hakkında Türkiye'nin gösterdiği her türlü ilgi ve alakanın tecavüzcülere dönük bir ihtar anlamına geldiği ifade edilmiştir. Yine yapılan yorumlar, nutkun Türkiye'nin açıkça ifade ettiği savaş dışı kalma siyasetini teyit etmiş olmasına rağmen Türkiye'nin hassas konumundan ötürü uyanık bir bekleme içinde bulunduğunu da anımsattığı açıklanmıştır. ${ }^{34}$

Türkiye'nin İngiliz basını tarafından övülen savaş dışı kalma politikası yine İngiltere tarafından eleştiriye uğrayacaktır. Bu kez İngiltere, 1941'in Ocak ayında kendi yanlarında savaş girmesi konusunda Türkiye'ye yönelik baskısını arttırmıştır. Savaş dışı bulunan ABD, Balkan ülkelerine destek olmak amacı ile çaba sarf etmiş ve bu amaçla Amerikalı bir albay 1 Şubat 1941'de Türkiye'ye gelmiştir. 14 Şubat 1941'de Başkan Roosevelt, Başbakan Refik Saydam'a mesaj göndermiş ve Alman saldırısına karşı direnecek ülkelerin "Kiralama ve Ödünç Verme Kanunu'ndan yararlandırılacağını belirtmiştir ${ }^{35}$. Görüldüğü üzere Türkiye'yi Müttefik bloğa çekmek için oldukça büyük bir çaba sarf edilmiş, fakat Türkiye'nin maksadı olabildiğince savaş dışı kalmak olmuştur.

Öte yandan savaş sürecinde Türk yöneticiler için izlenilen yol: "ne başkasının bir karış toprağında gözümüz var, ne de başkasına bir karış toprak veririz" biçimindedir. ${ }^{36}$ Ulus gazetesinin 2 Kasım 1941 tarihli manşetinde bu ifade yerini bulmuştur. TBMM'nin sürekli alkışları ve büyük tezahürleri arasında İnönü, Türkiye'nin iç ve dış politikasının ana hatlarını büyük bir vuzuhla anlatıışıı: "Hiçbir şart altında zor kabul etmeyiz! Millet yapısının sağlık ve sağlamlığı her vakit kıymetli dayancımız olacaktır." ${ }^{\prime \prime 7}$ Bu bağlamda yapılan her türlü baskının Türk Devletini yıldıramayacağı ve güçlü millet iradesi açık bir şekilde anlatılmaya çalışılmıştır.

Türkiye, savaş dışında kalma konusunda mücadele etmesine rağmen gerektiğinde ve topraklarına bir saldırı olması durumunda hiç düşünmeden savaşa iştirak edeceğinin sinyallerini de vermiştir. İnönü, Türkiye'nin saldırıya uğraması durumunda, yanında Müttefik devletler olmaksızın da savaşacağını söylemiştir. ${ }^{38}$ Bu bağlamda Tan gazetesi, İnönü’nün, Türkiye'nin iç ve diş siyasetini özetlediği söylediği nutkunda, hükümetin milletçe her fedakârlığı göze almak kararında bulunduğunu öne çıkardığını okuyucu kitlesine taşımıştır. ${ }^{39}$

Dünyayı gittikçe saran savaş ateşi karşısında İsmet İnönü'nün nutukları sürekli rahatlatıcı ve birleştirici olmuştur. İnönü 1 Kasım 1941'de yaptığı meclis konuşmasında, cesaretlendirici ve rahatlatıcı düşüncelerini şu şekilde ifade etmiştir:

"Bizi, hizmet ile şereflendiren büyük milletin emanetini, hepimiz canımızdan üstün tutarak vazife yapıyoruz. Büyük Meclisin ayrılığa ve aykırılığa asla yüz vermeyen tecrübeli idaresi, milletimizin başlıca dayancıdır.

34 Tan, 4 Kasım 1940, s.1-2. Londra'dan edinilen bilgiye göre, Cumhurbaşkanı İsmet İnönü'nün Türkiye Büyük Millet Meclisi’nde söylediği nutuk, İngiliz siyasî ve diplomatik mahfillerinde mükemmel bir surette karşılanmıştır. Türkiye'nin gayri muharip vaziyeti hayretle karşılanmak şöyle dursun, Türkiye'nin hakimane hareketinin yeni bir delili olarak kabul edilmiştir. "Reisicumhurun Nutkunun Akisleri: İngiliz Siyasî Ortamında Çok İyi Karşılandı”, Akşam, 4 Kasım 1940, s. 1.

35 Uçarol, a.g.e., s. 905.

36 Edward, Weisband, İkinci Dünya Savaşı'nda İnönü'nün Dış Politikası I, Çev: M. Ali Kayabal, Cumhuriyet Yayınları, İstanbul 2000, s. 27-28.

37 “Cumhurreisimizin Büyük Nutku”,Ulus, 2 Kasım 1941, s.1.

38 Akandere, a.g.e. s. 276

39 “Milli Şefin Nutku”, Tan, 4 Kasım 1940, s.1. 
Millet mukadderatının idaresi çok nazik olduğu bir devirde yaşıyoruz. Siyasette ana temellerimizin sade ve açık olmasından kuvvet alıyoruz. İçeride millî beraberliğe güveniyoruz. Bunu korumak için, gerekli olursa, her tedbiri almaktan sakınmayacağız." ${ }^{40}$

Ulus gazetesinde yazan Atay da, İnönü'nün konuşmalarının rahatlatıcı olduğundan bahsetmektedir. Atay, İnönü'nün nutkunun milletin bağrına bastığı bir nutuk olduğunu, özellikle milli siyasetle ilgili cümlelerin Türkiye'yi geniş ve kaplayıcı aydınlık içine aldığını vurgulayarak, Türkiye'nin ilişkide bulunduğu devletlerin hepsi için hem bugün hem de yarın emniyet sağlayacak olmasının, yapılacak hizmetlerin en iyisi biçiminde ifade etmiştir. ${ }^{41}$

Türkiye'nin toprak bütünlüğü düşünülerek savaştan uzak durulması ve barış yanlısı bir politika takip edilmesi M. Zekeriya Sertel'in "Millî Şefin Dış Siyasetimiz Hakkındaki Beyanatı" başlıklı yazısında yerini bulmuştur. Makalede Milli şefin verdiği nutuktan hareketle özellikle 3 nokta üzerinde durulmuştur: 1. Türkiye'nin dünyayı yangından ve 1stıraptan kurtarmak için barış unsuru olmaktan duyacağı sevinç, 2. Balkan milletlerinin bağımsızlıklarına kavuştuğunu görme isteğimiz, 3. Geleceğe dönük dış siyasetimizin ana hatlarını ifade edilmesidir. Sertel, Milli şefin verdiği nutkun sadece Türkleri aydınlatan vesika olmadığını aynı zamanda uluslararası konjonktürde de önemli olduğunu belirtmiştir. Ayrıca Türkiye'nin bu savaşta dimdik kalması, memleketin her tarafındaki birlik, yabancı emellere sürükleyici telkinlerin yayılma sahası bulamamış olması, millet yapısının sağlamlığı ve Türk ordusunun kuvveti ile açıklanmıştır. ${ }^{42}$

1940'ın Mayıs ayında Almanya'nın Fransa'ya saldırısı üzerine Türkiye savaş dışında kalma politikasını daha da keskinleştirmiştir. Bundan sonraki süreçte kendisi yenilgi alan bir devletin Türkiye'yi savaşa sokma yönünde baskı kurması beklenemezdi. İngiltere, Türkiye'yi Müttefiklerin yanında savaşa sokamayınca Türkiye'nin tarafsız kalma politikasını kabullenmiş fakat Türkiye'nin savaşa girmemesini bahane olarak görmüştür. Türk politikacıları, İngiltere'ye onların haklı davalarını desteklediklerini söylemekle birlikte, savaşa giremeyeceklerini belirterek, onları bu noktaya inandırmışlardır. ${ }^{43}$ Sovyet Rusya ve Almanya'ya da aynı şekilde açıklama yapan Türk yetkililer sağlam bir denge politikası yürütmeye çalışmış; öte yandan savaşa hazır bir pozisyon da almışlardır.

Bu doğrultuda 1943 yılının daha geniş ve daha insafsız muharebelerle geçeceğini düşünen İnönü ise meclisin altıncı dönem beşinci yasama yılı açış konuşmasında, Türkiye'nin imzaladığı antlaşmalara, ittifaklara ve dostluklarına sadık kalarak içerde ve dışarıda herkesçe bilinen milli siyasetini sürdüreceğini aktarmaktadır. Ayrıca gittikçe artan düşmanlık havası içerisinde tarafsız politika sürdürmenin hükümet için yorucu olduğunu da belirten İnönü, hükümetin herhangi bir devlete karşı hileli ve saklı fikirli olmaktan dikkatle sakındığını söylemektedir. Bu doğrultuda milli emniyet siyasetini takip edecek ve her devletle olan ilişkilerinin mahiyetini açıkça söylemekten çekinmeyecek Türkiye'nin, savaşın sonuna değin bu siyaset dürüstlüğünün devam edeceğini ifade eden İnönü, bu politikanın bütün muhariplerce de takdir edildiği kanaatindedir. Ayrıca bütün dünyayı saran harbin, yeryüzünde bir tarafın hâkimiyetine dayanan siyaset yapısının kalmayacağını ortaya serdiğine değinen İnönü, konuyu milletlerin eşit haklara sahip olmasına getirmiştir. Buradan hareketle İnönü, küçük büyük bütün milletlerin yeryüzünde istiklal ve haysiyetle yaşamak imkânına sahip bulunacağını, bu gayenin ise Türkiye'nin uluslararası siyasette daima esas prensibi kabul edildiğini belirtmiştir. ${ }^{44}$

40 Tarihe Düsülen Notlar-1, Yasama Yılı Açılışlarında Cumhurbaşkanlarının Konuşmaları-1 (1 Mart 192414 Arallk 1987), TBMM Yayınları, Ankara 2011, s.127.

41 Falih Rifk1 Atay, "Nutuk Bir Vazifeler Düsturudur”, Ulus, 4 Kasım 1941, s.1.

42 M. Zekeriya Sertel, "Milli Şefin Dış Siyasetimiz Hakkındaki Beyanatı”, Tan, 3 Kasım 1941, s. 1

43 Mustafa Aydın, "İkinci Dünya Savaşı ve Türkiye, 1939-1945”, (Editör, Baskın Oran), Türk Dış Politikası, C.1, İletişim Yayınları, İstanbul 2014, s. 425-428.

44 Tarihe Düşülen Notlar-1, Yasama Yılı Açılışlarında Cumhurbaşkanlarının Konuşmaları-1 (1 Mart 192414 Arallk 1987), TBMM Yayınlar1, Ankara 2011, s. 102-103. 
İnönü’nün değerlendirmesini destekler mahiyetteki yorumlar dış basında söz konusu olduğu gibi İnönü’nün şahsında Türkiye'nin dış siyasetini öven yazılar da söz konusudur. Bu bağlamda Lozan'da çıkan Gazettede Lausanne: "Türkiye iftihar duymakta haklıdır. Memleketi harpten uzak tutmak için sarf ettiği gayretler minnetle karşılanmaktadır. Harp Türkiye hudutlarına tehlikeli surette yaklaşmaktadır."

Yine Lozan'da çıkan Liberal gazetelerden ve Katolik partisinin organı olan Courrier de Geneve gazetesi şunları yazmaktadır:

"Türkiye Cumhurbaşkanı, memleketinin muhariplere karşı tam bir tarafsılılık olan dış siyasetini değiştireceğini ima etmemekle birlikte Ankara'nın muharip devletlerle münasebetlerinde muhafaza ettiği denge Türkiye'ye sadece harp dışında kalmasını sağlamamış bu memlekete aynı zamanda maddi menfaatler de temin etmiştir. 1943'te görülecek daha şiddetli ve daha merhametsizce muharebeler ihtimali karşısında Türk Devlet Şefinin milletine verdiği parola orduyu hazır bulundurmak ve uyanıklığından hiç bir şey gevşetmemek olmuştur."

Aynı konuda Alman kontrolü altında bulunan Romanya'da çıkan bir Rumen gazetesi: “Türkiye bitaraflığını uluslararası dostluk münasebetleri çerçevesine sokmuştur" ${ }^{\text {"47 }}$ yorumunda bulunmuştur.

Dış basında görüldüğü gibi Türkiye'nin, savaşa girmesi istenmemekte ve savaşın başından beri devam ettirdiği bitaraf politikası arzulanmaktadır. İsviçre basınında Türkiye'nin tarafsızlığını sürdüreceğine yönelik İnönü’nün konuşmasının özellikle yoğun ilgi gördüğü anlaşılmaktadır. Bunun en önemli nedeni şüphesiz İsviçre basının Almanya’ya yakın yayın yapmasında aranabilir. Neue Berner Zeitung'in neşrettiği bir yazı şu şekildedir:

“Ankara, menfaatleri gereği birbirleriyle harp halinde bulunan büyük devletlerle olan ilişkilerinde denge temininde mükemmel bir surette başarılı olmuştur. İnönü, son derece nazik bir zamanda Atatürk'ün mirasını muhafaza vazifesi ile karşı karşıya bulunuyor. İnönü, bu mirası hiç bir zarara uğratmaksızın dünya sulhuna kavuşturmak azmindedir. Türkiye Cumhuriyeti, hükümet başkanının bu yoldaki gayretlerinden dolayı iftihar edebilir. Özellikle son üç savaş yıllarında görüldüğü gibi Ankara hükümeti, bu devletin kurucusu Atatürk'ün, her şeyi Türk gözü ile görmek prensibine aynen sadık kalmıştır ve bundan sonra da sadık kalacaktır”.

Basler National-Zeitung gazetesi “Türkiye Boş Emniyet Hislerine Kapılmıyor” başlı̆̆ı altında neşrettiği bir yazıda kısaca şu yorumu yapmaktadır: “Türkiye'nin ne kadar doğru düşüncelerle hareket ettiğini ve onu idare edenlerin bugünkü vaziyetin ortaya attı̆ğ imkânları ne kadar ciddî bir surette göz önüne aldıklarını İnönü’nün son nutku açıkça ispat etmiştir”"48 değerlendirmesinde bulunmuştur. Anlaşılacağı üzere Alman basını da Türkiye'nin tarafsızlı̆̆ından hoşnuttur.

Türk basınına göre sadece Alman ve Alman taraftarı gazeteler değil, bütün Avrupa gazeteleri de İnönü’nün nutkunu ilgi ile karşılamıştır. Bükreş’te Universul gazetesi, Türkiye Cumhurbaşkanının nutku hakkında fikir yürüterek, Türkiye'nin dış siyasetinin savaşın başlangıcından itibaren güç imtihanlar geçirdiğini, savaştan uzak kalmayı prensip olarak azmetmiş bulunan Türkiye'nin kesin bitaraf vaziyet aldığını ve bu bitaraflığını uluslararası dostluk münasebetleri içerisine soktuğunu yazmaktadır. ${ }^{49}$

Sofya'da çıkan Utro gazetesinde Prof. Genoff, Türkiye Cumhurbaşkanı İsmet İnönü’nün nutku hakkında yayınladığı makalesinde Türkiye'nin katı bitaraflık hususunda şimdiye kadar takip ettiği görüşüne sadık kaldığını, fakat cumhurbaşkanın aynı zamanda, bu nutukta, Türkiye'nin bugün harbe her zamankinden yakın bulunduğunu söylediğini de dikkat çekmektedir. Prof. Genoff'a göre, Türkiye'nin barış içinde kalmak hususundaki arzusundan

\footnotetext{
45 “Milli Şef’in Son Nutku ve İsviçre Basınının Yaptığı Tefsirler”, Ulus, 6 Kasım 1942, s. 1.

46 "Leman'da Çıkan Ve Katolik Partisinin Organı Olan Caurrier De Geneve Gazetesi Şunları Yazmaktadır”, Ulus, 6 Kasim 1942, s. 1.

47 “Şefimizin Nutku Etrafında, Hariçteki Tefsirler Devam Ediyor”, Tan, 5 Kasım 1942, s. 1.

48 "Cumhur Reisimizin Nutku Her Tarafta Büyük Akisler Yaptı”, Akşam, 4 Kasım 1942, s. 1.

49 “Reisicumhurun Nutku: Bütün Avrupa Gazeteleri Nutuktan Büyük Bir Alâka İle Bahsediyor”, Akşam, 5 Kasim 1942, s. 1.
} 
kimse şüphe edemez. Çünkü barış Türkiye'nin hakiki milli menfaatlerine uygundur. Türkiye'nin doğrudan doğruya komşusu olan Bulgarlar bu gayretin muvaffak meyve vermesini ve böylece dünyanın bu mevkiinde bar1şın muhafaza edilmesini temenni etmektedir. ${ }^{50}$ Anlaşılacağ aynı zamanda Türkiye'nin emniyeti için de Balkan coğrafyasının sulh içinde bulunmasını temenni ettiğinden Türkiye'nin bitaraf politikasını sürdürmesinden hoşnuttur.

İnönü'nün nutkunu destekleyen dış basından başka Türk basını da kaleme aldığı makalelerle hükümetin ve hükümet başkanı İnönü’nün sergilediği siyasetin arkasında durmuştur. Ulus gazetesinde yazan F. Rifkı Atay, Cumhurbaşkanı İnönü'nün 1 Kasım 1942'de TBMM'de söylediği nutkun, yeni Türkiye siyasi tarihinin başlıca belgeleri arasında kalacağını belirterek, İkinci Dünya Savaşı'nın dördüncü yılında Türkiye'nin hem dış hem de iç politikalarının başarılı bir izahı olduğunun da altını çizmektedir. Dünyayı kan ve ateş içine alan savaşla ilgili Türkiye'nin görüşü, yeryüzünde sadece bir tarafın hâkimiyetine dayanan bir siyasetin savaş neticesinde kurulamayacağı yönündedir. Bu nedenle Türk hükümeti, büyük küçük bütün milletlerin yeryüzünde barış içerisinde yaşamasını milli politika biçiminde ele almıştır. Bu milli politika etrafında Türk hükümeti de milli emniyet sistemine devam ederken daha önce verdiği sözlerin ve imzaladığı antlaşmaların arkasında durarak, açık diplomasi yürütecektir. ${ }^{51}$

Tan gazetesinde yazan Burhan Belge de, İnönü’nün hem kendi hem de 18 milyon Türkün dünya görüşünü bir dünya vatandaşı sıfatı ile haykırdığını belirtmektedir. Buna göre yarınki dünyada büyük ve küçük milletler barış içinde bir arada yaşayacaklardır. ${ }^{52}$ İnönü'nün nutuklarının genelinde olduğu gibi gazete başmakalelerinde de bütün milletlerin barış içerisinde yaşayabilmesi umudu ve temennisi sürekli olarak ön plandadır.

Bu doğrultuda, İnönü'nün nutkunda, savaşın başından beri devam ettirilen Türk dış siyasetinin toplu değerlendirmesini yaptığını ileri süren Akşam gazetesinde yazan Necmeddin Sadak, Türkiye'nin bütün devletlerle sürdürdüğü, temeli barış olan emniyet siyasetinin bugünün dünyası tarafından tanındığını belirtmektedir. Üstelik bu milli siyasetin muhariplerce tanınmasını ve kabul edilmesini, Türkiye'nin savaşan tarafların her ikisiyle de dostluk ve karşılıklı güven esasına dayanan siyasetinin olgunlaşmasına bağlamaktadır. Ancak Sadak, mevcut açık siyasete rağmen, gittikçe şiddetini artıran savaş ortamında, bitaraf politika sürdürmenin çok yorucu olduğunu açıkça belirten, yine de takip edilen siyasetin gelecek günlerde de değişmeyeceğini kesin bir dille söyleyen İnönü’nün, ülkesinin günün birinde hürriyet ve istiklali uğruna silaha sarılması durumunda kabahatin Türkiye'de olmayacağını da ortaya koyduğunu aktarmaktadır..$^{53}$

İnönü'nün de belirttiği gibi 1942 yılı Türkiye için zor bir yıl olmuş ancak 1943 yılı daha zorlu geçmiştir. 1943 'te Müttefikler sürekli olarak Türkiye'ye çeşitli antlaşmalarla kendilerinden yana bir seçim yapmalarını istemişlerdir. ${ }^{54}$

\subsection{Türkiye-Almanya İlişkileri}

Türkiye'nin Balkan devletlerine yakın olması Almanya tarafından İngiliz etkisi olarak algılanmış ve bu alg1 Türk Alman ilişkilerini olumsuz etkilemiştir. 12 Mayıs 1939'da Türk-İngiliz yardım deklarasyonunun imzalanmasından beş gün önce Türkiye'nin Almanya'ya ısmarladığ tüm savaş araç gereçleri durdurulmuş buna karşılık Türkiye, Almanya’ya sattığı kromun miktarını azaltıış ve gönderimini yavaşlatmıştır. Akabinde iki devlet

50 "Reisicumhurun Nutku: Bütün Avrupa Gazeteleri Nutuktan Büyük Bir Alâka İle Bahsediyor”, Akşam, 5 Kasim 1942, s. 1.

51 Falih Rifk1 Atay, "Devlet Reisimizin Nutku”, Ulus,1 Kasım 1942, s. 1, 3.

52 Burhan Belge, “Türkiye'de Bir Şef Yaşar”, Tan, 2 Kasım 1942, s. 1-2.

53 Necmeddin Sadak, "Cumhurreisimizin Nutkunda Türkiye’nin Dış Politikası”, Akşam, 3 Kasım 1942, s. $1-2$.

54 Aydemir, a.g.e. s. 254. 
arasında daha önce imzalanan Ticaret Antlaşması yenilenmemiş ve 1 Eylül 1939'da ticaret tümüyle durmuştur..$^{55}$ 1940'da Alman ilerleyişine paralel olarak ilişkilerde bir düzelme gözlenmesi ve Türkiye'nin tarafsılı̆ğının belirlenmesiyle birlikte bu durum hem Almanya hem de Türkiye için rahatlamaya sebep olmuş, akabinde de 25 Temmuz 1940'da Türk Alman Ticaret Antlaşması yapılmıştır. ${ }^{56}$

Türk-Alman ilişkileri bu şekilde ilerlerken 28 Ekim 1940'da İtalya'nın Yunanistan'a saldırması Türkiye'yi zor durumda bırakmıştı. Çünkü İngiltere ve Fransa ile yapılan ittifak antlaşmasına göre İngiltere, Yunanistan ve Romanya'ya garanti vermişti. Verilen garantiye göre; savaş çıkması durumunda Türkiye İngiltere ve Fransa'nın yanında yer alacaktı. ${ }^{57}$ Savaş esnasında meydana gelen bu gelişmeler dış basında yankısını bulmuştur. Sofya'da Türkiye'nin İtalyan - Yunan harbinin haricinde kalmak niyetinde olduğu belirtilmiş ve İsmet İnönü'nün Türkiye'nin İngiltere ile mevcut olan anlaşmaya bağlı olması sadece bir formaliteden ibaret görülmüştür. ${ }^{58} \mathrm{Bu}$ bağlamda Sofya'da Türkiye'nin savaşa girme gibi bir niyetinin olmadığı anlaşılmış ve basına yansımıştır.

4 Kasım 1940 tarihli Tan gazetesinde Sertel “İtalya-Yunan Harbi Önünde Türkiye’nin Vaziyeti” başlıklı başmakalesinde İtalya-Yunan savaşı başladığından beri Türk vatandaşının kafasında yer alan: "1.Biz harbe girecek miyiz? 2. İtalya, Yunanistan'la meşgul iken Almanya Bulgaristan üzerinden Türkiye'ye inmek isteyecek midir? 3. İtalya-Yunan savaşı bize geçecek midir? 4. Türkiye ne zaman kendisini savaşa girmeye mecbur sayar? bu tarz sorulara cevap aramıştır. Türkiye savaşa girecek mi? sorusuna Sertel, İnönü’nün meclis kürsüsünden Türkiye'nin sınırları dışında bir karış toprakta gözünün bulunmadığı yine Türkiye'nin hayati menfaatlerine saldırı niyetinde olmayan bir devletin de Türkiye'nin siyasetinden endişe etmemesi gerektiğini belirten sözleriyle en güzel cevabı verdiğini ifade etmiştir. Sertel, İnönü’nün bu sözlerinden yola çıkarak Türkiye'nin harbe girmeye mecbur olması için emniyetine ve hayati menfaatlerine bir saldırının gerekli olacağından hareketle Mihver devletlerin şimdiye kadar Türkiye'ye karşı böyle bir saldırı siyaseti takip etmediklerini, Almanya'nın Türkiye'nin savaş dışı kalmasını istediğini belirtmiştir. Sertel, Almanya'nın menfaatini Balkanlarda Türkiye ile bir savaşa girmemek ve bu kış Yakın Doğu'da başına bir bela açmamak şeklinde yorumlamıştır. ${ }^{59}$ Diğer taraftan Yunanistan'a yapılan bir saldırının Türkiye'nin güvenlik sahasına bir tehdit oluşturduğu sırada Türkiye ittifak antlaşmaları ile Yunanistan'a yardım etmek mecburiyetinde midir? şeklinde soruya ise İnönü’nün nutkundan hareketle müttefikimiz İngiltere hükümeti ile durumun ortaklaşa ele alınacağını söylemiştir. Balkan Paktı'na göre İtalya tarafından saldırıya uğrayan Yunanistan'a Türkiye'nin yardım etmesi söz konusu değil fakat Bulgaristan tarafından bir saldırı gerçekleşirse Türkiye'nin Yunanistan'ın yardımına koşabileceği vurgulanmıştır. ${ }^{60}$

Dış basında yer alan bilgilere göre Türkiye'nin her şekilde bağımsızlığını ve bütünlüğünü koruma çabasında olmasının yanında İnönü yaptığı meclis konuşmasından yapılan alıntıda, Sovyetler Birliği ile Türkiye ilişkilerinin samimi bir biçimde yeniden kurulmasından Almanların hiç de memnun olmayacağı belirtilmiştir. Yine İnönü'nün nutku söyleyeceği gün Alman elçisinin Berlin'e gitmiş olmasının da özellikle seçildiği ifade

55 Ayrıntılı bilgi için bkz; Koçak, Türkiye'de Milli Şef Dönemi (1938-1945), C. I, s. 386-440.

56 Uçarol, a.g.e., s. 901.

57 Armaoğlu, a.g.e. s. 408.

58 "Reisicumhurun nutkunun akisleri: İngiliz siyasî ortamında çok iyi karşılandı” Akşam, 4 Kasım 1940, s. 1.

59 M. Zekeriya Sertel “İtalya-Yunan Harbi Önünde Türkiye’nin Vaziyeti”, Tan,4 Kasım 1940, s. 1-2.

60 İtalya bir balkan Devleti olmadığı gibi İtalya'dan gelecek taarruza karşı yardım, Yunanistan’ın kendi isteği ile anlaşma hükümleri dışında bırakıldı. Hatta 1939 Ağustos'unda İtalya'dan gelecek taarruza karşı yardım, Yunanistan'ın kendi isteği ile olan bağlarından dolayı endişelerini belirttiği zaman Yunan Başbakanı Metaksas cevap olarak, Yunanistan'ın Türkiye'ye karşı yalnız Balkan Antantı içinde taahhütleri bulunduğunu ve bunun da İtalya'ya karşı olmadığını söylemişti. (Mehmet Gönlübol- Cem Sar, “1919- 1939 Dönemi”, Olaylarla Türk Dış Politikası, Siyasal Kitabevi, Ankara 1996, s. 148). 
edilmiştir. ${ }^{61}$

Ulus gazetesi 5 Kasım tarihli nüshasında İnönü’nün son nutku etrafında Romen ve Bulgar basının yorumlarını haberleştirerek bir Bulgar gazetesinin “nutuk Yakın Doğu'daki vaziyet üzerinde bol ve aydınlık verici bir aydınlık serpmiştir” şeklindeki çıkarımı gazetesine taşımıştır. Yine Bükreş kaynaklı Rador ajansının Universal gazetesinde birinci sayfadan verilen haberinde, İsmet İnönü'nün nutku tahlil edilerek şu şekilde bir sonuca ulaşı1dığı ifade edilmiştir. Buna göre: “1. İtalyan-Yunan harbi Türkiye'nin emniyet sahasına dayanmıştır, 2. Bu sahanın hududu, Türkiye için birinci derecede ehemmiyeti haizdir. 3. Türkiye, İngiltere ile anlaşma halinde hazırlamakta bulunduğu kararını henüz almamıştır." şeklinde yorumlar gazeteye taşınmıştır. ${ }^{62}$ Görüldüğü gibi İtalya'nın Yunanistan'a saldırması esnasında dış basında yer alan haberlerden yola çıkıldığında Türkiye'nin İtalyan tehdidi üzerine savaşa girme ihtimali yüksek görülmüştür. Nitekim bu öngörüler doğru çıkmamıştır.

1941 savaşın bütün hararetiyle devam ettiği bir yıl olarak karşımıza çıkmıştır. Almanya'nın Balkanlardaki faaliyetleri ve Bulgaristan'a saldırması Türkiye'de büyük bir kaygı yaratmıştı. Almanya bu kaygıyı giderme girişimlerinde bulunmuş ve Türkiye'ye saldırmayacağı konusunda garanti vermiş bir taraftan da Türkiye'ye Mihverlerin yanında olması için baskı uygulanmıştır. 8 Haziran 1941'de Menemencioğlu, Alman Dışişleri Bakanı von Papen'e açık bir şekilde ne İngiliz ne de Alman zaferini istediklerini, dolayısıyla, Türkiye'nin istikrarlı bir Orta Avrupa dileğini izah etmiştir. ${ }^{63}$ Almanya, zamanla Türkiye'nin tarafsılzlığını kabullenmiş ve 18 Haziran 1941'de Almanya ve Türkiye arasında dostluk ve saldırmazlık antlaşması imzalanmıştır. ${ }^{64}$

Bu durum Akşam gazetesinde haberleştirilerek, İnönü'nün sözleriyle, antlaşmanın getirdiği güvenlik ortamı kamuoyuna yansıtılmıştır: "Haricî siyasetimiz, taahhütlerimize sadakatle devam edecektir. Türk-Alman muahedesinin karşılıklı bir itimat havası yarattığını memnuniyetle kaydetmek isterim." ${ }_{65}^{5}$ Görüldüğü gibi taraflar arasındaki güven ve itimat İnönü’nün konuşmasına yansımıştır.

Tan gazetesi de İnönü’nün sözleriyle Türk-Alman antlaşmasını şu şekilde değerlendirmiştir: “Ahitlerimizin samimi yolunda yürüyeceğiz. Hiçbir şart altında zor kabul etmeyeceğiz. Türk-Alman dostluk ve saldırmazlık muahedesinin hükümleri her şart içinde mahfuz olarak devam ediyor ve devam edecek. Memleketimiz bir gün dünyanın muhtaç olduğu barışın kaynağı olabilirse bundan duyacağımız sevinç pek büyük olacaktır” ${ }^{66}$ Görüldüğü üzere farklı gazetelerde benzer ifadeler kullanılmıştır.

Ulus gazetesine göre ise İnönü söylediği nutukla, Türkiye'nin dış ve iç siyasetin ana hatlarını açı ve keskin cümlelerle anlatmıştır. ${ }^{67}$ Tarafsızlık politikasını vurgulayan İnönü düşüncelerini şu şekilde ifade etmiştir: "Tarafsızlık politikası yürütmek, hükümet için çok yorucu olmaktadır. Biz, her devletle olan münasebetlerimizin mahiyetini açıkça söyleyebilir bir karakterde ve kuvvette olduğumuz için politikamızı gelecekte de sebatla takip etmekten çekinmeyeceğiz. Siyasetimizdeki dürüstlüğün her tarafa ait faydalarının, bütün muhariplerce takdir edildiğini sanıyoruz." ${ }^{68}$ İnönü burada Türk dış politikasının dürüst ve aynı çizgide olduğunu vurgulamaya çalı̧̧mıştır. Dürüst ve istikrarlı politika basında da yankısını bulmuştur.

Bu bağlamda Tan gazetesi bitaraf siyaset takip eden Türkiye'nin dünya harbine en ziyade bugün yaklaştı-

61 Tan, 4 Kasim 1940, s. 1-2.

62 Ulus, 5 Kasim 1940, s. 1.

63 Koçak, Türkiye'de Milli Şef Dönemi (1938-1945), C. I s. 556.

64 Koçak, Türkiye'de Milli Şef Dönemi (1938-1945), C. I s. 587.

65 “Millî Şefin Mühim Nutku”, Akşam, 2 Kasım 1941, s.1.

66 "BMM Dün Saat 15 de Açıldı", Tan, 2 Kasım 1941, s. 1. Gazetenin aynı sayısında, nutkun hülasası şeklinde hazırlanan bir kutucukta nutuk özetlenmiştir.

67 Ulus, 2 Kasim 1942, s. 1.

68 Tarihe Düşülen Notlar-1, Yasama Yllı Açılışlarında Cumhurbaşkanlarının Konuşmaları-1 (1 Mart 192414 Aralık 1987), TBMM Yayınlar1, Ankara 2011, s. 128. 
ğını söyleyen İnönü’nün sözleriyle hükümetin içinde bulunduğu zorlu durumu kamuoyuna yansıtmıştır:

"İnönü memlekette hakiki kuvvetlerimizi sağlam vaziyetimizi bulandırıp gölgelendiren bir manevi telaş ve 1stırap havasının estiğine işaret etti. Istırabı azaltmak, millet tahammülünü arttırmak ve muharebeye girilirse şerefle selametle çıkmak için tek çare hükümete candan yardım etmektir. Kahraman ve kıymetli ordumuzu hazır bulundurmamız bugün her zamandan ziyade lazımdır. Önümüzdeki sene dahi milli siyasetimizin herkesçe bilinen istikametlerini dürüst ve ciddi olarak muhafaza edeceğiz." ${ }^{\prime 69}$

İnönü, savaş süresince tedbiri elden bırakmadığı gibi bir takım tedbirler de almıştır. Bunlardan en çok tartışılanı Varlık Vergisi’ydi. Bu verginin amacı savaş zenginlerini, fırsatçıları kazandıkları servetler üzerinden vergi vermeye zorlamak olmuştur. Vergi protestolarla karşılaştı. Meclisteki görüşmelerde bile kanuna aykırı olduğu bile söylenmişti. ${ }^{70}$ Her alanda hazırlıklı olunduğu gibi savaşa girmeye mecbur kalındığında ülkenin en iyi şekilde savunulması için halkın desteği istenmiş ve dürüst bir siyaset takip edilmiştir. ${ }^{71}$

Aynı günlerde Akşam gazetesi İnönü’nün sözleriyle gelişmeleri şu şekilde değerlendirmiştir:

"Patladığ1 günden beri dünya harbine memleketimiz en ziyade bugün yaklaşmıştır. Sağlam vaziyetimizi bulandırıp gölgelendiren bir manevî telâş ve 1stırap havası bugün vatanımızın üzerinde esmektedir. Yeryüzünde bir tarafın hâkimiyetine dayanan bir siyaset yapısının kurulamayacağı anlaşılmaya başlanmıştır, öyle görünüyor ki 1943 yılı daha geniş ve daha insafsız muharebelerle geçecektir. Taahhütlerimize, ittifaklarımıza, dostluklarımıza sadık olarak millî emniyet siyasetimizi takip edeceğiz."ᄁ2

Sofya basınından aktarıldığına göre; İnönü tarafından Türkiye'nin harp dışında kalma konusundaki azmi, memnuniyetle karşılanmıştır. Ayrıca cumhuriyetçi Türkiye'nin güttüğü siyasette hâkim fikirlerden birini teşkil eden Balkan milletlerinin istiklâli ile ilgili fikirleri belirtilmiştir. ${ }^{73}$ Sofya basınında yer alan haber Türkiye'nin güttüğü savaş stratejisiyle birebir uymaktaydı. Bu stratejide bilindiği üzere savaş dışı kalma stratejisiydi. ${ }^{74}$

Fransa'nın Vichy şehrinden yapılan aktarmalar; İnönü’nün, esasları yalnız iki unsura işaret eden bu nutkundaki büyük sadeliğe bilhassa dikkati çekmektedir. Bu unsurlardan biri hakkında pek iyiliksever sözler kullandığı Almanya, öteki de hakkında pekiyi kelimeler sarf ettiği İngiltere'dir. Nutkunda ne Sovyetler Birliği'ne dair bir kelimeye ne de Atlantik ötesi memleketleri için bir imaja rastlanılmamıştır. Birkaç mutedil kelimeyle dünyanın 1stıraplı tablosunu çizerken hatta bu sadelik içinde bile ne kadar heyecanlı davranıldığı belirtilmiştir. ${ }^{75}$

Başlıca gazetelerin kullandıkları başlıklar şunlardır: Times'in başlığı: "Türkiye boyun eğmiyor."’76 Daily Telegraph'ın başlığı: "Türkiye Hitler'in dâvasına iltihak etmemiştir, Türkiye İngiltere'nin dostu olarak kalıyor." News Chronicle'in başlığı: “İnönü, Türkiye'nin ahitlerine sadık kalacağını söylemiştir.” Daily Mail'in başlı̆̆ı: "Türkler sulh olacağını ümit etmiyorlar, fakat sulh yapılmasını teklif ediyorlar."’77 Başlıklardan da anlaşıldığ kadarıyla Türkiye sürekli savaş dışı kalmayı tercih etmiş ve barış yanlısı bir politika takip etmiştir.

69 "Meclis Milli Şefimizin Nutku İle Açıldı”, Tan, 2 Kasım 1942, s. 1.

70 Edward, Weisband, İkinci Dünya Savaşı’nda İnönü’nün Dış Politikası III, Çev: M. Ali Kayabal, Cumhuriyet Yayınları, İstanbul 2000, s. 24-25.

71 "Meclis Milli Şefimizin Nutku İle Açıldı”, Tan, 2 Kasım 1942, s. 1.

72 "Meclis Bugün Açıldı Reisicumhur Diyor Ki”, Akşam,1 Kasım 1942, s. 1.

73 “Inönü’nün Nutkunun Yankıları, Türk Sulhçuluğu Her Tarafta Takdir Ve Hayranlık Uyandırdı", Ulus, 3 Kasım 1941, s. 3.

74 Ayrıntılı bilgi için bkz; Weisband, İkinci Dünya Savaşı'nda İnönü’nün Dış Politikası I, s. 17-32.

75 “İnönü’nün Nutkunun Yankıları, Türk Sulhçuluğu Her Tarafta Takdir Ve Hayranlık Uyandırdı”, Ulus, 3 Kasim 1941, s. 1.

76 Ulus, 4 Kasım 1941, s.1.

77 Ulus, 4 Kasim 1941, s.1. 


\subsection{Türkiye- Sovyet Rusya İlişkileri}

Savaşın başında Türkiye Sovyet Rusya ile ilişkilerini iyi tutmaya çalışmış bir taraftan da İngiltere ve Fransa ile görüşmeleri sürdürmüştür. Sovyet Rusya, Türkiye ile antlaşma yapmak amacıyla Türk Dışişleri Başkanını Moskova'ya çağırmıştır. Sovyet Rusya Alman tehlikesi karşısında Türkiye'yi yanında tutmaya çalışmış fakat Almanya’ya öncelik vermiş ve 23 Ağustos 1939'da Almanya ile Saldırmazlık Paktı imzalamıştır. Türkiye bu esnada 12 Mayıs 1939'da İngiltere ve 23 Haziran 1939'da Fransa ile Karşılıklı Yardım Deklarasyonu imzalamıştır. Böylece Türkiye ve Sovyet Rusya birbirlerine karşı olan devletlerle anlaşma imzalamışlardır. ${ }^{78}$ Bu gelişmeler üzerine Dışişleri bakanı Şükrü Saracoğlu, heyetiyle birlikte 25 Eylül'de Moskova'ya gitmiş ve Sovyet Rusya Dışişleri Bakanı Molotov ile resmi görüşmeler gerçekleştirmiştir. ${ }^{79}$ Görüşmeler esnasında Sovyet Rusya, boğazlarla ilgili taleplerde bulunmuştur. Talepler Türk heyeti tarafından şaşkınlıkla karşılanmıştır. Akabinde 1 Ekim 1939'da başlayan görüşmelerde Sovyetler isteklerini tekrar etmiştir. Boğazlar üzerindeki geçiş statüsünü kendi lehlerine değiştirilmesini ve Boğazlar üzerinde ortaklık talepleri Saraçoğlu tarafindan reddedilmiş ve antlaşma sağlanamadan geri dönülmüştür. ${ }^{80}$ Türk heyeti dönüş yolundayken İngiltere ve Fransa ile antlaşma yapılmıştır. Rusya ile anlaşmanın sağlanamaması, Falih Rıfkı Atay'ın Ulus gazetesindeki yazısında ifadesini bulmuştur.

Falih Rıfkı Atay "Cumhurreisimizin Nutku” isimli yazısında İngiltere ve Fransa ile bir ittifak antlaşması yapılmasının yanında Sovyet Rusya ile ne kadar çok istenilse de böyle bir ittifakın yapılamamış olmasının TürkSovyet ilişkilerinin hem geçmiş hem de gelecek de dostane çizgisine zarar vermeyeceğinin altını çizmiştir. ${ }^{81}$ Atay, iki noktayı vurgulamış bunlardan biri Türkiye'nin barış yanlısı olduğu, diğeri Rusya ile ilişkilerini geçmişteki gibi dostane bir şekilde sürdürme isteğidir.

Türkiye'nin barışçı politikasını Necmeddin Sadak, Akşam gazetesindeki makalesinde vurgulamaya çalışmıştır. Sadak dış siyaset noktasında Türkiye'nin istiklaline ve bütünlügüne saygı gösteren ülkelerin, Türkiye'nin siyasetinde değişiklikler beklemesine lüzum olmadığını belirterek, Türkiye'nin barışı devam ettirme hususunda dış politikasını Sovyet dostluğu ve İngiltere ittifakı şeklinde iki noktaya dayandığını belirtmiştir. ${ }^{82}$ Açıkçası Türkiye, hem batılı devletler hem de Sovyetler ile iyi geçinmeyi amaçlamıştı. ${ }^{83}$

Öte yandan Türkiye'nin İngiltere ve Fransa ile imzaladığı antlaşmaya Rusya'nın tepkisi çok sert olmuştur. Sovyetler bu antlaşmayı aptallık olarak değerlendirmiş ve bir süre sonra Türkiye'ye yaptığı petrol sevkiyatını durdurmuştur. Rusya'ya göre bu antlaşma ile Türkiye tarafsızlığını terk etmiştir. ${ }^{84}$

Ancak İnönü, 1 Kasım 1940'da yaptı̆̆ı meclis açılış konuşmasında, Sovyetlerle ilişkilerin giderek düzeldiğine vurgu yapılmıştır. Bu konuşma dış basında da yankısını bulmuştur. Tan gazetesi, nutkun bazı sol görüşlü gazetelerde özelliklede News Chronicle gazetesinde, Sovyetler Birliği ile ilişkilerin iyileştiğine yönelik kısımların okuyucuların dikkatlerine sunduğunu ön plana çıkarmaktadır. ${ }^{85}$ Nitekim1940 yılının nisan ayından hazirana kadar Alman saldırıları devam etmiş sırasıyla Danimarka, Norveç, Hollanda, Belçika işgal edilmişti. ${ }^{86}$ Aynı yıl içerisinde Almanya, Macaristan ve Romanya’yı işgal etmiş ve zamanla bütün Balkanlar Almanya'nın etkisine

\footnotetext{
78 Uçarol, a.g.e, s. 894.

79 Koçak, Türkiye'de Milli Şef Dönemi (1938-1945), C. I, s. 267.

80 Kamuran Gürün, Türk-Sovyet Illişkileri (1920-1953), TTK Yayınlar1, Ankara 1991, s. 203-208

81 Falih Rifk1 Atay, “Cumhurreisimizin Nutku”, Ulus,2 Kasım 1939, s. 2.

82 Necmeddin Sadak, "Bütün Millet, Kahraman Şefine: "Seninle Beraberiz!” diyor”, Akşam, 3 Kasım 1940, s. 1.

83 Akandere, a.g.e, s. 272.

84 Akandere, a.g.e. s. 274.

85 Tan, 4 Kasım 1940, s.1-2.

86 R.A.C.Parker, II. Dünya Savaşı, Dost Kitabevi, Ankara 2005, s. 37.
} 
girmeye başlamışt1. ${ }^{87}$ Almanya'nın ilerleyişi Türkiye ve İngiltere'yi endişeye düşürdüğü gibi Rusya'yı da endişeye düşürmüştü. Bu endişe Rusya'yı Türkiye'ye yaklaştırmış ve 25 Mart 1941'de Türkiye ve Rusya arasında ortak bir deklarasyon yapılmıştı. Deklarasyona göre: iki devletten biri saldırıya uğraması durumunda diğeri onun tam anlayış ve tarafsızlığına güvenebilecekti.

Yine Lyon kaynaklı haberde ise Fransız gazetesi Temps'de İnönü’nün özellikle Türk-Sovyet ilişkilerinin samimileşmesi yönünde söylediği sözler ön plana çıkarılarak doğu bölgesinde günün en önemli haberi şeklinde nitelendirilmiştir. ${ }^{88}$ Yine gazete İnönü’nün nutkunun Sovyetlerle olan kısmının son derece önemli olduğunu üzerinde durmasının yanı sıra İngiltere ile ilgili olan beyanını da manidar bulduğunu ifade etmiştir. Türkiye'nin bekleme hattıhareketi tuttuğunu ifade eden gazete, bu hareket hattının da Türk arazisinin emniyeti ve Türkiye'nin hayati menfaatlerine ve ittifaklarına mani olmayacağını söylemiştir. ${ }^{89}$

Savaşın ilerleyen süreçlerinde niyetler değişmiş ve 22 Haziran 1941'de Almanya, Sovyet Rusya'ya savaş açmıştır. Bu süreçten sonra Sovyet Rusya, Türkiye'ye toprak teklifinde bulunmuş ve teklif Türkiye tarafindan reddedilmiştir. Değişen diplomasi istek ve niyetlere faklı bir yön vermiştir ${ }^{90}$.

\section{1942-1945 Arası Dönem}

\subsection{Türkiye - Müttefik Devletler İlişkileri}

1941 yılının sonuna doğru başlayan Alman-Rus savasının ardı sıra Japonya'nın da Amerika’ya saldırması, Sovyetler ile Amerika'nın Müttefik Devletlerinin, Japonya'nın ise Mihver Devletlerinin yanında savaşa dâhil olmasına neden olmuştur. Bu durum 1943 yılına kadar yani Almanya'nın Stalingrad Savaşı'nı kaybetmesiyle sonuçlanacak yeni bir denge kuracaktır. ${ }^{91}$ Nitekim Kızıl Ordu'nun 1942 yılının Kasım ayında başlattığı genel saldırının akabinde Alman ordusunun 1943 yılında Stalingrad'ta mağlup olması Almanların gerilemesini beraberinde getirmiştir. Aynı süreç içerisinde Almanların Kuzey Afrika'da da geri çekilmesi Müttefik ve Mihver Devletlerin Türkiye üzerindeki politikalarının değişmesine sebebiyet vermiştir. Müttefikler Türkiye'nin kendi yanlarında savaşa girmesini isterken, Mihver güçleri de savaşın bu son aşamasında Türkiye'nin savaş dışı tutumunu sürdürmesi için faaliyet göstereceklerdir..$^{92}$

Ancak diğer taraftan, Stalingrad Savaşı sonrasında ortaya çıkabilecek "Rus tehlikesinden" endişe duyan Türk karar alıcılar gerektiği vakit Türkiye'nin hürriyet ve istiklali uğruna savaşa girebileceğine de vurgu yapmışlardır. Ne de olsa Stalingrad Savaşı İkinci Dünya Savaşı'nın ilerleyişinde dönüm noktasıydı; bu nedenle Türkiye, Müttefik zaferini daha güvenli bir vizyonla desteklemeye başladı. Bununla birlikte, mezkûr savaş ve Kuzey Afrika'daki Müttefik zaferi, Türkiye'nin savaşa girmesini garanti etmedi, çünkü Almanya hala Türkiye'deki önemli şehirleri bombalayabilecek ve ülkeyi işgal edebilecek bir konumdayd $1 .{ }^{93}$ Diğer taraftan ise Türkiye kuzey komşusu Sovyet Rusya'nın Almanya karşısında elde ettiği zafer neticesinde hem tedirgin olacak hem de diş politika dengelerinde değişikliğe giderek iç politikada belirgin Alman yanlısı bir politika sergileyecektir. ${ }^{94} \mathrm{Bu}$ aşamada yine Türkiye Alman yanlısı olarak bilinen Numan Menemencioğlu'nu Dışişleri Bakanlığı görevine

\footnotetext{
87 Uçarol, a.g.e. s. 860.

88 Tan, 4 Kasim 1940, s. 1-2.

89 Ulus, 5 Kasim 1940, s. 1.

90 Akandere, a.g.e., s. 599.

91 Armaoğlu, a.g.e., s. 339.

92 Koçak, Türkiye’de Milli Şef Dönemi (1938-1945), C. I, s. 141.

93 Ayşegül Avcı, "Winning the war of perception: american attempts to counter Germany's military influence in Turkey during World War II", Turkish Studies, Vol. 17, No. 1, 2016, s. 210.

94 Süleyman Seydi, “1939-1945 Dönemi İç ve Dış Politika”, Ed: Adem Çaylak vd., Osmanlı’dan İkibinli Yıllara Türkiye’nin Politik Tarihi, Savaş Yayınevi, Ankara, s. 280.
} 
getirecektir. ${ }^{95}$ Diğer taraftan Türkiye'nin müttefiki İngiltere, 1943'te çıkarlarının birbirine karşıt olduğunu kabul ettiği iki devlet Türkiye ve Rusya'yı müttefikleri arasında görmek gibi inanılmaz bir durumla karşı karşıya kalmışt1. ${ }^{96}$ Bu bağlamda İngilizler 1939 Üçlü İttifak Antlaşması'yla Türkiye'nin savaşta etkin işbirliğini sağlamanın beklentisi içerisindeydi. Türkiye, İngiltere ile imzaladığı ittifak antlaşmasını bir savunma antlaşması biçiminde yorumlarken; İngilizler, Türkiye'yi yanlarına almaya çalıştı. Ne var ki İnönü, ülkenin hayati çıkarları açıkça tehlikede olmadıkça, savaş sırasında Türkiye'yi tarafsız tutmaya kararlıydı. İnönü, savaşın başlangıcından 1943'ün sonlarına kadar İngilizlerin Türkiye'yi yaygın ve aktif düşmanlıklarda bir insan gücü kaynağı olarak kullanabileceğini arzu ettiğini vurgulayacaktır. Ancak dış politikada Türkiye 1943 yılı içinde iki muhasım kampı da kollayarak savaşın dışında kalabildi fakat 1943'ten sonra İngilizler, üsler için Türk topraklarının kullanılmasında 1srar etti. 1939 İttifak Anlaşması'na ilişkin iki tarafın bu farklı algıları, Anglo-Türk çelişkilerine yol açtı. Karar verme sürecinde etkili olan Türk diplomatlarının ve üst düzey yetkililerinin aynı zamanda en başından beri savaşa aktif olarak katılmaya isteksiz oldukları söylenebilir. İkinci Dünya Savaşı'ndaki Türk politika hedefi egemenliği ve bağımsızlığı güçlendirmek için savaştan uzak durmak ve böylece ülkeyi yıkıcı etkilerinden kurtarmaktı. Bu anlamda, politika oldukça açık, basit ve kesindi. ${ }^{97} \mathrm{Bu}$ bağlamda Müttefik Devletler ve İngilizler arasında gerçekleşen Kazablanka Konferansı'nın sonunda, Türkiye'nin savaşa katılımı için planlar hazırlayan İngiltere Başbakanı Winston Churchill, Türkiye ile ilgili stratejilerini yerine getirme konusunda tam yetkiyi de elde etti. Buna göre askeri teçhizat sağlayarak Türkiye'yi tam olarak desteklemek Churchill'in birinci; Türkiye'nin güney kesimini, herhangi bir İtalyan saldırganlığına karşı korumak, ikinci; tam koruma sağlamak için Türk hava üslerine ve hava alanına erişebilmek ise üçüncü stratejisiydi. Kazablanka Konferansı'nda İngilizler, savaştan sonra Türkiye'nin toprak bütünlüğüne zarar verebileceğine dair Ruslardan duydukları korkuyu kullanarak Türkleri savaşa aktif olarak girmeye ikna etmeleri gerektiğine karar verdiler. ${ }^{98}$

Böylece Kazablanka'da kararlaştırıldığı üzere İngiltere Başbakanı Churchill, Türkiye'yi savaşa sokabilmek için Müttefikler adına Adana'ya gelerek İnönü ile görüşmüşse de Türk heyetini ikna edememiştir. ${ }^{99}$ Yapılan görüşmede Churchill, Sovyetler Birliği'nin gelecek on yılda, Müttefiklerin de yardımına ihtiyaç duyacağı, yeniden kalkınma ve imar faaliyetleriyle fazlasıyla meşgul olacă̆ı argümanından yola çıkarak, Türkiye'nin Sovyetler Birliği'nden duyduğu endişeyi bertaraf etmeye gayret etmiştir. İlaveten komünizmin değişime uğramasından dolayı Sovyetler Birliğì'nin İngiltere ve Amerika ile iyi ilişkiler kuracağına dair inanç besleyen Churchill, Türkiye'yi İngiliz ve Amerikan yardımı alarak Almanya’ya saldırmaya ikna etmeye çabalamıştır. ${ }^{100}$ Ancak İnönü, eğer savaşa girerse Türkiye'nin, hazırlıklı olamayacağı ve ülkeye İngiltere'den yeterli destek gelemeyeceği sebebiyle Almanya'nın saldırısı karsısında savunmasız kalacağını iddia ederek, tarafsız kalmayı tercih ettiğini bildirmiştir. ${ }^{101}$ Diğer taraftan Churchill'in angajman istemesi ancak bir milletin bir diğerine saldırısını önlemek için düzenlemeler yapacak ve savaştan sonra geleceği şekillendirilecek Konsey'de Türkiye'nin bir sandalyeye sahip olması için çok önemliydi. ${ }^{102}$ Bütün bu gelişmeler neticesinde Türkiye her ne kadar savaşa girmeme kararında 1srarcı olsa da Müttefikler lehine bir eğilim göstermeye başlamıştır. Nitekim Türkiye iki cephe Mihver ve Sovyetler Birliği cephesi üzerinden tehdit altında kalmıştır. Bu durumda İnönü, Türkiye'nin hem jeopolitik hem de jeostratejik konu-

95 Weisband, İkinci Dünya Savaşı'nda İnönü’nün Dış Politikası I, s. 32.

96 Weisband, İkinci Dünya Savaşında İnönü`nün Dış Politikası II, s. 45

97 Cenap Çakmak, “Turkey In The Second World War: "Evasive” Or "Active” Neutral?”, Akademik Araştırmalar Dergisi, S. 26, 2005, s. 65.

98 Hakan Özden, “The Diplomatic Maneuvers of Turkey in World War II", Karadeniz Araştırmaları, Bahar 2013, S. 37, s. 101.

99 Mustafa Yılmaz, “İnönü Dönemi Türk Dış Politikası”, Selçuk Üniversitesi Atatürk İlkeleri ve İnkılap Tarihi Araştırma ve Uygulama Merkezi Dergisi, Sayı: 8, Konya 1999, s. 22

100 Aydın, a.g.m., s. 452.

101 Hale, a.g.e., s. 92.

102 Özden, a.g.m., 102. 
mundan kaynaklı savaşa girmesi durumunda karşı tarafça işgal edilebileceği fikrini işlemiştir. İlaveten böyle bir saldırı karşısında yer alabilecek Türkiye'nin savaş teçhizatı bakımından yetersiz kalacağını ortaya koymuştur. ${ }^{103}$

Savaşa girmeme konusunda 1srarcı olan Türkiye için başka planlara sahip Müttefikler, Ağustos 1943 y1lında Quebec'de (Kanada) gerçeklesen konferansta birtakım karara vardılar. Buna göre, Türkiye'nin savaşa katılmasının henüz erken olduğunu belirten Müttefik Devletler hem Balkanlar'da açılacak yeni bir cephe için önem arz eden Türk havaalanlarının derhal Müttefiklerin kullanımına açılmasını hem de Türkiye'nin askerî gücüne katkı yapmaya devam edilmesini öne çıkardılar. Ancak aynı zamanda Müttefikler, Türkiye'nin Almanya'ya ihraç ettiği kromu durdurması ve Boğazlar'dan geçen Alman gemilerini engellemesi gibi konularda Türkiye'ye yönelik baskıyı artırmaya karar verdiler. ${ }^{104}$ Çünkü Müttefiklerin değerlendirmesiyle Türkiye'nin 1943 yılı başından beri izlediği tarafsız politikası kendi davalarına zarar verdiği gibi bu politika artık Almanya'nın yararına sonuçlar doğurmaktaydı. Bu nedenle Türkiye'nin siyaseti Balkanlar üzerinden Avrupa'ya girmeyi planlayan Müttefik ordularının önünde bir engeldi. ${ }^{105}$ Özellikle İngiltere, Balkanlara yönelik bir askeri harekât için 1943 y1lı içerisinde Türkiye'nin savaşa dâhil olması konusundaki talebini hem Amerika hem de Sovyetler Birliği'ne kabul ettirmişti. Türkiye'nin savaşa girmesi için baskı oluşturan İngiltere, doğrudan savaş sonrası ortamında Sovyet tehdidiyle karşı karşıya kalabileceğini Türkiye’ye belirtmiştir. Türkiye ise Müttefikler tarafından kendine yapılan baskılara rağmen tavrında bir değişikliğe gitmemiş, böylece savaş Boğazlar ve Yakın Doğu bölgesine yayılmamıştır. ${ }^{106}$ İngilizlerin yanı sıra Sovyetler Birliği de 1943 yılında gerçekleşen Moskova Konferansı'nda Türkiye'nin savaşa dâhil edilmesi konusunda kararlı bir tutum sergilemiştir. Neticede Moskova Konferansı'nda, Türk havaalanlarının Müttefikler tarafından kullanılmasına ve 1943 yılının sonuna kadar Türkiye'nin savaşa dâhil edilmesi kararına varıldi. ${ }^{107}$

Müttefikler Türkiye ile ilgili karara varırken, 1935 yılından itibaren dış siyasetinde tuttuğu yolda ilerleyen Türkiye, bu siyaset sayesinde İkinci Dünya Savaşı'nın beşinci senesine ulaşmıştır. Savaşı önlemek için en cesur hareketlere atılan Türkiye'nin, milletlerin esir seviyesine düşmemesi için gerektiğinde metin bir durum almaktan çekinmeyeceğini belirten İnönü, yarınki dünya şekillenirken de her zaman çökmeye mahkûm tahakküm zihniyetinin aksine büyük ve küçük bütün bağımsız milletler arasında samimi işbirliğine dayanan bir nizamın kurulmasını beklemektedir. Savaş dışında olmakla beraber savaşın her türlü ıstırabına gögüs geren Türkiye'nin insaniyet ve medeniyetin galip gelmesi için fedakârlıklara katlandığını aktaran İnönü, uluslararası durumdan etkilenecek Türk milletinin kendi içinde ve beraber olarak TBMM'nin etrafında büyük bir kudret olarak hem kendi vatanını imar edeceğini hem de hür ve müstakil milletlerin faydalı bir üyesi olacağını belirtmektedir. Müttefiklerin elde ettikleri zafer neticesinde savaşın 1944 senesi içerisinde sona erebileceğini söyleyen İnönü, Türk milletinin şeref ve itibarının da gelecek ihtimaller içinde daha fazla yükseleceği kanaatindedir. Nitekim dünya harbinin galibinin insaniyet ve medeniyet olmasını temenni eden İnönü, bu doğrultuda hizmette bulunacakların ayrılıkta değil, birleşmede dünya kurtuluş ve saadetine hizmet edeceğine değinmektedir. ${ }^{108}$

İnönü’nün yukarıda yer alan, meclis yedinci dönem ikinci yasama yılı açış konuşması bir Rumen gazetesinde: “İnönü’nün nutku yüksek hislerin bir ifadesidir”'109 biçiminde değerlendirilmiştir. Dışarıda bu tarz yapılan

103 Baskın Oran, “ 1939-1945: Savaş Kaosunda Türkiye: Göreli Özerklik-2”, Türk Dış Politikası, C.1, Editör: Baskın Oran, İletişim, İstanbul 2014, s. 395.

104 Aydın, a.g.m., s. 455.

105 Koçak, Türkiye'de Milli Şef Dönemi (1938-1945), C. 2, s. 165.

106 İsmail Soysal, Türk Dış Politikası İncelemeleri İçin Kılavuz, İstanbul 1993, s. 15.

107 Suat Bilge, Türkiye-Sovyetler Birliği İlişkileri 1920-1964: Güç Komşuluk, Türkiye İş Bankası Kültür Yayınlar1, Ankara 1992, s.188-191.

108 Tarihe Düşülen Notlar-1, Yasama Yılı Açılışlarında Cumhurbaşkanlarının Konuşmaları-1 (1 Mart 1924- 14 Aralık 1987), TBMM Yayınları, Ankara 2011, s. 108-109.

109 “Bir Romen Gazetesi Diyor Ki: İnönü’nün Nutku Yükselt Hislerin Bir İfadesidir”, Ulus, 5 Kasım 1943, s. 1. 
yorumlar, sadece milletlerin hürriyet ve istiklalleri esasına göre hareket eden Türkiye'nin, savaşı önlemek için en cesur hareketlere tereddütsüz atıldığının bir göstergesidir. Atay, İnönü’nün sözlerinin hem hür ve güvenlik içinde yaşamak isteyen Türklerin, hem de nizam ve medeniyete hizmet etmek isteyen her insanın gönlünde yer bırakacağına şüphe etmediğini ifade etmektedir. Yine İnönü'nün sözlerinden hareketle Türkiye'nin büyük ve küçük bütün hür milletler arasında samimi bir işbirliğine dayanan bir düzenin kurulacağına inandığını belirten Atay, böylece Türkiye'nin tutacağı yolun da adalet düzeninin kurulmasına yardım edeceğini öne çıarmaktadır. Ancak Atay, gelecek senenin savaş buhranını artıracağından dolayı, İnönü'nün Türk milletini uyanık tuttuğunu da ilave etmektedir ${ }^{110}$.

Akşam'da yazan Sadak da, Türkiye'nin gayesinin, hiç bir zaman ayakta duramayacak bir baskıcı zihniyetinin değil, büyük küçük bütün hür milletler arasında işbirliğine dayanan bir düzenin kurulduğunu görmek olduğunu söylemektedir. Böylece Türkiye'nin, bu dünya savaşından önce yani 1935 İtalya'nın Habeşistan'a saldırmasından beri hiç korkmadan baskıcı tutuma karşı koyma siyasetini seçtiğini, mezkûr savaş içinde herkesin ümitsiz olduğu zamanlarda bile bu düşünceden ayrılmadığını, yarın da ayrılmayacağını ifade etmektedir. Buna göre İnönü’nün, savaşın dışında kalan Türkiye'nin gayesi uğruna seçtiği siyaset yolu hiç bir tereddüde yer bırakmayacak şekilde anlattığını belirten Sadak, dünya politikacılarına ve yarını hazırlayanlara asil bir örnek verdiğini vurgulamaktadir. ${ }^{111}$

Tan gazetesinde yazan Sertel, İnönü’nün TBMM kürsüsünden söylediği nutkunda, medeniyetin yık1liş1 ve insanlığın felaketi karşısında öncelikle, baskının değil, insaniyet ve medeniyetin galip çıkmasını istediğini ifade etmektedir. İnönü'nün bu değerlendirmesinden yola çıkan Sertel, Türkiye'nin diş siyasetine temel olan başlıca ana prensiplerin yine bu temennilerden kaynaklandığını söylemektedir. Sertel, çarpışan kuvvetlerden birinin (Almanya) diğer milletlere (Müttefikler) baskı yaparak bir dünya hâkimiyeti peşinde olduğunu, diğerinin (Müttefikler) ise hürriyet adalet ve insanlığın refahı için savaştığını söylemektedir. Buradan yola çıkan Sertel, Türkiye'nin büyük ve küçük bütün bağımsız milletler arasında samimi bir işbirliği arzu eden İnönü’nün sözlerinden hareketle, Türkiye'nin dış siyasetine tarafsızlığın üstünde bir istikamet verildiğini söylemektedir. Buna göre yazar, Türkiye'nin artık dünyada baskıcı politika güderek savaş gayesi edinen milletlere karşı sempati gösteremeyeceğinden dolayı yarınki dünya düzeninde hür ve müstakil milletlerle serbest işbirliği yapması gerektiğinden, bu noktada savaşan milletlere yardım etmekten çekinmeyeceğinin altını çizmektedir. Neticede Sertel, savaş sonrası düzende bütün küçük ve büyük milletlerin hür ve bağımsız olmasında 1srarcı bulunan Türkiye'nin de bu hür ve bağımsız milletler içinde faydalı bir üye olacağının altını çizmektedir. ${ }^{12}$ Böylece Sertel, Türkiye'nin baştan beri tuttuğu Müttefiklerin yanında olma siyasetini desteklediği gibi Müttefikler için de Türkiye'nin yenidünya düzenine ve barışına katkı sunacak düzeyde bir stratejik ortak olduğunu da belirtmiştir.

Türkiye üzerine yapılan baskılar etrafında, Kasım 1943'te bu kez Kahire'de yapılan görüşmelerde, yeniden Türkiye'nin savaşa dâhil edilmesi meselesi gündeme alınmıştır. ${ }^{113}$ İngiliz Dışişleri Bakanı Anthony Eden ile Türkiye'nin Dışişleri Bakanı Numan Menemencioğlu arasında gerçekleşen görüşmelerde Eden, "Sovyet Kozu”nu ileri sürmüş ancak Türkiye, yeteri kadar yardım yapılmadıkça kesinlikle savaşa katılmayacağını Dışişleri Bakanı Menemencioğlu aracılığ ile Müttefiklere bildirmiştir. ${ }^{114}$ Türkiye savaş dışı kalma politikasını Kahire'de devam ettirirken daha önce planlandığı gibi üç büyük müttefik devletin başkanları Churchill, Stalin ve Roosevelt Aralık 1943'te Tahran'da buluştular. ${ }^{115}$ Tahran Konferansı'nda yine Türkiye'nin bir an önce savaşa dâhil olması ve

110 Falih Rifk1 Atay, “Cumhurreisimizin Nutku”, 2 Kasım 1943, Ulus, s.1, 3.

111 Necmeddin Sadak, "Emniyet Havası İçinde İnsanlara Temiz Nefes Aldıracak Bir Adalet Nizamı İstiyoruz", Akşam, 2 Kasım 1943, s. 1.

112 M. Zekeriya Sertel, "Milli Şefimizin Dış Siyasetimize Ait Yeni Direktifleri”, Tan, 2 Kasım 1943, s. 1.

113 Antonello Biagini, Çağdaş Türkiye Tarihi, Phoenix, Ankara 2007, s. 87.

114 Necdet Ekinci, İnönü Dönemi ve II. Dünya Savaşı Ylllarl, Genel Türk Tarihi, Ankara 2002, s. 656

115 Armaoğlu, a.g.e., s. 353. 
Almanlar üzerine ikinci bir cephenin açılması meseleleri gündeme taşınmıştır. ${ }^{116}$

Tahran Konferansı'nın akabinde bu kez Türkiye Cumhurbaşkanı İsmet İnönü, İngiltere Başbakanı Winston Churchill ve ABD Başkanı Franklin D. Roosevelt arasında Kahire Konferansı adı verilen görüşmeler Kahire'de gerçekleşmiştir. ${ }^{117}$ Üç devlet başkanının görüşmesinde Müttefikler açık biçimde savaşın galip tarafı olduklarını, buna rağmen halen tarafsızlığını sürdürmede ısrarcı bulunan Türkiye'nin savaş sonrasında tecrit edileceğinin işaretini verdiler. ${ }^{118}$ Churchill, Türk karar alıcılara açık biçimde Türkiye'nin Bulgaristan sınırındaki savaşa girmesini istedi. Yine Churchill, Türkiye'nin savaşa girmesi durumunda Stalin'in yardım sözü verdiğini de sözlerine ekledi. İkinci Dünya Savaşı'nı inceleyen birçok politik tarihçi Kahire Konferansı'nda İnönü’nün askeri teçhizat eksikliği savını savaşa girmekten kaçınmak için bir bahane olarak kullandığını iddia etmiştir. Ancak bu argüman bir bahane değil aksine Türkiye'nin içinde bulunduğu şartların gerçeğidir. ${ }^{119}$ Bu gerçekliğe rağmen Kahire'de yapılan görüşmelerde baskıların artması üzerine Türkiye ilk defa prensip olarak savaşa katılmaya razı oldu ancak bu durum Türk ordusuna gerekli silah ve donanımın temini koşuluna bağlanmıştır. ${ }^{120}$ Belirlenen bu koşul etrafında Kahire'de kararlaştırıldığı gibi Türkiye'nin savaşa hazırlanması için askeri heyetler temas içerisine girmiştir. Ancak yürütülen askeri temaslardan sonuç alınamamıştır. 4 Şubat 1944'te kesilen bu görüşmeler İngiltere'nin Türkiye'ye karşı "soğukluk politikası" uygulamasını başlatmıştır. Türk dış politikasını yürütenler, İngiltere'yi gücendirmek pahasına savaşa girmeme yönünde kararlılık gösterirken, İngiltere'nin savaş sonrasında Sovyetler ile kaçınılmaz olarak girecekleri rekabetten dolayı ve çıkarları gereği Türkiye ile iyi ilişkilere gireceğine inanmaktaydılar. ${ }^{121}$

\subsection{Türkiye-Almanya İlişkileri}

1941 yılının sonuna doğru Alman-Rus savasının başlamasının akabinde Almanya’nın uğradığı mağlubiyet Türkiye-Almanya ilişkilerini de etkileyecektir. Bu doğrultuda Türkiye'ye yönelik politikasını değiştiren Almanya, Türkiye'yi kendi yanında savaşa dâhil etme düşüncesinden ayrılarak Balkanların güney sınırını güvence altında tutabilmek amacıyla hareket edecektir. Bu bağlamda Almanya, Türkiye'nin kendisine karşı Müttefiklerin yanında savaşa katılmasını engellemek ve tarafsızlığını sürdürmesi için gayret sarf edecektir. Dahası Müttefik Devletlerin baskısına karşı durabilmesi maksadıyla Türkiye'ye destek sağlayacaktır. Mezkûr amaçları doğrultusunda hareket eden Almanya, 18 Nisan 1943'te Türkiye ile bir ticaret antlaşması imzalamıştır. İmzalanan ticaret antlaşmasıyla hem iki ülke arasında ticaretin gelişmesi sağlanmış hem de, 1943 yılı sonuna kadar Almanya, daha önce vaat ettiği silahları Türkiye'ye teslim etmiş; Türkiye de, Almanya'ya ihraç ettiği krom miktarını yükseltmiştir. ${ }^{122}$ Amaçları doğrultusunda hareket eden Almanya karşısında Türkiye'nin politik aktörlerinden İnönü de Alman yanlısı bir iç politika gütmeye başlarken ${ }^{123}$ Alman taraftarı olarak tanınan Numan Menemencioğlu'nu Dışişleri Bakanlığı makamına atayacaktır. ${ }^{124} \mathrm{Bu}$ değişim İngilizlerin Türkiye üzerinde nüfuzunun azalması izlenimini doğursa da Menemencioğlu, savaş boyunca Türk diş siyasetinin şekillenmesinde aktör durumunda olacaktır. ${ }^{125}$

116 Hale, a.g.e., s. 87.

117 Uçarol, a.g.e., s. 918.

118 Erick Jan Zürcher, Modernleşen Türkiye’nin Tarihi, (Çev: Yasemin Saner Gönen), İletişim Yayınları, İstanbul, 2007, s. 297.

119 Özden, a.g.m., s. 104.

120 Uçarol, a.g.e., s. 918.

121 Yilmaz, a.g.m., s. 23.

122 Uçarol, a.g.e., s. 916.

123 Seydi, a.g.m., s. 280.

124 Weisband, İkinci Dünya Savaşı’nda İnönü’nün Dış Politikası I, s. 32. Ayrıntılı bilgi için bakınız; Selim Deringil, Denge Oyunu, Tarih Vakf1 Yurt Yayınları, İstanbul 2014, s. 42-57.

125 Deringil, a.g.e., s. 5-6. 
Bunun yanı sıra Müttefik baskısıyla özellikle bir İngiliz baskısıyla karşı karşıya kalan Türkiye üzerinde, 1943 Ağustos'unda Kanada'da düzenlenen Quebeck Konferansı'nda Müttefiklerin vardıkları karar, Balkanlar'da açılacak yeni bir cephe için gerekli olan Türk havaalanlarının derhal kullanımının sağlanmasıdır. Ayrıca Türkiye'nin askerî gücüne sunulan katkı1 sürdürmek niyetinde bulunan Müttefikler, Türkiye'nin Almanya'ya ihraç ettiği kromu durdurması ve Boğazlar'dan geçen Alman gemilerini engellemesi gibi konularda Türkiye'ye yönelik baskının artırılmasına karar verdiler. ${ }^{126}$ Ancak 5 Haziran 1944'te Boğazlardan Karadeniz'e bazı Alman savaş gemilerinin geçmesi, Türkiye ile Müttefiklerin arasının daha da açılması sonucunu doğurmuştur. Bu olay sonunda Dışişleri Bakanı Numan Menemencioğlu görevinden istifa etmiştir. ${ }^{127}$ Almanya ile ilişkilerini kesen Türkiye, böylece Müttefiklerin gözünde puan toplamak isteyecektir.

Bu kapsamda tarafsız dış siyasetini sürdüren Türkiye, İngiltere ile ittifakının neticesinde Almanya ile ekonomik ve diplomatik münasebetlerini TBMM kararıyla kesmeye karar vermiştir. İnönü'nün yorumuyla bu tarihi karar milli iradenin çok önemli ve isabetli bir eseridir. Artık dünya savaşının Müttefikler lehine kesin neticeli safhasına girdiğini belirten İnönü, gelecek sulhun insanlığa adaletli, küçük büyük her millet için emniyetli bir devir getireceğini ummaktadır. Milletlerin istiklâlini ve emniyetini koruyan yeni bir düzen kurmak için büyük devletlerin elbirliğiyle çalışmağa muvaffak olacağına inanan İnönü, Türkiye'nin, milletler ailesinde faydalı ve yardımcı bir uzuv olarak elinde olan her gayreti sarf edeceğini aktarmaktadır. Ayrıca Birleşik Amerika ile Türkiye arasındaki münasebetler İkinci Dünya Savaşı esnasında daha da artarak dostane mahiyet kazanmıştır. İnönü’ye göre iki ülke arasındaki dostluk münasebetleri gelecekte daha geniş ve daha yakın olacaktır. Yine nutkunda Türkiye'nin, İngiltere ile ittifakına, Amerika ile dostluğuna, Sovyet Rusya ile ise savaş döneminde aradaki anlaşmalarla tespit edilen ilişkilerine riayet ettiğini belirten İnönü, hatta bu münasebetlerin ileride daha fazla gelişeceği ümit ettiğini belirtmiştir. ${ }^{128}$

Bu doğrultuda Atay, Türkiye'nin hem iç hem de dış politika çerçevesinde başarılı bulunduğunu, üstelik aksayan taraflarına rağmen elde edilen başarının "milletin" başarısı olduğunu ifade etmektedir. İlaveten yazar, gerek devlet reisi gerek meclis ve hükümetin etrafında barış günleri gelinceye kadar Türk milletinin vazifesinin ve mesuliyetinin çok üstünde bir gayrette bulunması gerektiğinin üzerinde durmaktadır. ${ }^{129}$

Sadak'a göre de Türkiye dış siyaseti bağlamında, bu savaşın başından beri herkesin bildiği tek, açık yolda yürümüştür. İngiltere ile ittifakına ve vatan topraklarına yapılacak her taarruzu silâhla karşılamak kararına dayanan bu siyaset etrafında Türkiye'nin gereksiz maceralardan kaçındığı kadar, her ne pahasına olursa olsun kendini müdafaa azminden de şaşmadığı Sadak tarafından ifade edilmektedir. Bu bakımdan Sadak, Alman saldırısını Müttefiklerin en zayıf zamanında Balkanlar'da durdurarak Orta Doğu'ya savaşı bulaştırmayan Türk siyasetinin gerek İngiltere'ye, gerek Sovyet Rusya'ya yaptığı yardımlar üzerinden çok konuşulduğunu aktarmaktadır. Ayrıca Sadak, savaşın Müttefik zaferine yaklaştığı ortamda, Türk-İngiliz ittifakının taze ve canlı mahiyetini muhafaza etmesiyle, Türkiye'nin bu beş yıllık savaş içinde oynadığı değerli rolün İngiltere tarafından iyice anlaşıldığını belirtmektedir. Yine Sadak, İnönü'nün öteden beri çizdiği Türkiye'nin dış siyasetinin, Almanya ile ekonomik ve diplomatik münasebetlerin kesilmesinden doğan dikkate değer durumla yeni bir merhaleye ulaştığını ve bu tarihi kararın, beklenen neticeleri verdiğini söylediğini belirtmektedir. Böylece Türkiye milletler ailesi içinde, milletlerin istiklâlini ve emniyetini koruyan yeni bir düzen kurmak için büyük devletlerin işbirliğine inanarak çalışan, barış ve istikrar unsuru biçiminde faydalı ve yardımcı bir devlet olarak her gayreti sarf edecektir. Balkan milletleri ile de barış ve sükûnet içinde dostça yaşayan Türkiye'nin büyük devletlerle ittifakına ve dostluğuna dayanarak kendi emniyet bölgesinde hiç şüphesiz yatıştırıcı, barıştırıcı bir rol oynamağa namzet olduğunun da altı çizilmek-

126 Aydın, a.g.m., s. 454- 455.

127 Akandere, a.g.e. s. 304.

128 Tarihe Düşülen Notlar-1, Yasama Yılı Açıllş̧larında Cumhurbaşkanlarının Konuşmaları-1 (1 Mart 1924- 14 Aralık 1987), TBMM Yayınları, Ankara 2011, s. 118.

129 Falih Rifk1 Atay, Devlet Reisimizin Nutku”, Ulus, 2 Kasım 1944, s. 1. 
tedir. Balkanlar'da ise barışın sağlanması Sadak'a göre büyük devletlerin savaş sonunda anlaşmasına ve özellikle de Balkanlara büyük devlet nüfuzunun girmemesine dayandırılmıştır. Ancak böyle şartlarla bölgenin herkes için emniyet ve barış bölgesi olacağı ön plana geçirilmiştir. Kısacası Türkiye'nin gerek komşularıyla, gerek savaşın galipleriyle mevcut diş siyaseti bir sulh ve istikrar siyaseti biçiminde tarif edilmiştir. ${ }^{130}$ Fark edileceği üzere basın, Türkiye'nin Müttefikler içinde ittifakla bağlandığı İngiltere ve savaş sırasında kendisine yakın bulduğu Amerika ile her zaman ve her koşulda aynı paralelde bulunduğunu öne çıkarırken, Sovyetlerin savaşı kazanan Müttefik cephenin bir üyesi ve coğrafi konumundan ötürü Türkiye açısından her zaman dikkat edilmesi gereken bir ülke olması nedeniyle, Sovyetlere daha 1lımlı ve yumuşak bir tutum içerisine girmiştir.

Türk basının da ortaya koyduğu Türk dış siyaseti etrafında Türkiye, mezkûr sulh ve istikrar siyaseti etrafında Almanya ile olan ilişkilerini savaşın sonuna doğru kesecektir. Bu doğrultuda Müttefik Devletlerin, Almanya ile olan ticari ve diplomatik ilişkilerin kesilmesi yolunda baskılarının artması üzerine Türkiye 20 Nisan 1944'te Almanya'ya yaptığı krom sevkiyatını durdurduğunu açıklamıştır. ${ }^{131}$ Müttefikler krom meselesini işine gelir biçimde çözdükten başka bu defa da Türkiye'nin Almanya ile diplomatik ilişkilerini kesmesi için baskıda bulunmaya başladılar. Zaten savaşın sonuna yaklaştığını sezen Türkiye de Batılı devletlerin yanında yer almak istiyordu. Eğer bunu yapmazsa, tamamen yalnızlığa itileceğinin farkındaydı. Anlaşılacağı üzere Türkiye İngiltere'nin baskısı neticesinde 2 Ağustos 1944〉te TBMM'nin aldığı kararla Almanya ile tüm ilişkilerini kesmiştir. ${ }^{132}$

Böylece 1944 yılı itibariyle Türkiye savaşın başından beri izlediği tarafsızlık siyasetinin seyri dışına çıkarak, ancak İngiltere ile imzaladığı ittifakın çerçevesi içerisinde Almanya ile ekonomik ve diplomatik münasebetlerini kesmiştir. Bu karar İnönü’ye göre milli iradenin çok önemli ve isabetli bir eseridir. Diğer taraftan İnönü, İkinci Dünya Savaşı'nın Müttefikler lehine kesin neticeli safhasına girdiğini dolayısıyla milletlerin istiklalini ve emniyetini koruyan yeni bir düzen kurmak için büyük devletlerin elbirliğiyle çalı̧̧acağı ve muvaffak olacağı kanaatine sahiptir. Türkiye'nin de milletler ailesinin faydalı bir üyesi olarak çalışacağını söyleyen İnönü, Türkiye'nin savaş esnasında birçok fedakârlığa katlanan ve istırap çeken ülkelerle dostluk içerisinde ilişkilerini devam ettireceğini ifade etmektedir. Birleşmiş Milletler içerisinde yer almak isteyen Türkiye'nin iç idaresinde de daha demokratik ve milli bir siyaset takip edeceğinin sinyallerini veren İnönü, hükümetin TBMM'nin kesintisiz kontrolü altında varlığını devam ettirirken; Türk milletinin de iç ve dış politikada yapılan her konuda bilgi sahibi bulunduğunu aktarmaktadır. ${ }^{133}$

\subsection{Türkiye- Sovyetler Birliği İlişkileri}

1943 Şubat'1 başında Rusların Almanlara karşı Stalingrad zaferini kazanmalarından itibaren Rusya'nın Türkiye'yi tehdit eden siyaseti yeniden kendini göstermeye başlamıştır. ${ }^{134}$ Nitekim Müttefiklerin düzenledikleri ikili veya üçlü konferanslarda Türkiye meselesi sık sık ele alınacaktır. Bu hususta Churchill ve İnönü arasinda gerçekleştirilen Adana Görüşmeleri'nden sonra Türkiye'nin Müttefik Devletlerle birlikte savaşa girme meselesi Kahire'de iki dışişleri bakanının görüşmelerine taşınmıştır. ${ }^{135} 5$ Kasım 1943 'te bir araya gelen İngiliz Dışişleri Bakanı Eden, Türkiye'nin Dışişleri Bakanı Menemencioğlu'na Moskova Konferansı'nın kararlarını sunmuştur. Türkiye ile Sovyetler Birliği arasındaki ilişkilerin yumuşaması için çaba sarf eden İngiltere karşısında Menemencioğlu, Türkiye'nin bir an önce savaşa katılmasını isteyen Sovyetlerin, Türkiye'nin savaşta

130 Necmeddin Sadak, “Devlet Reisinin nutku: Dış siyasetimiz”, Akşam, 4 Kasım 1944, s.1.

131 Hale, a.g.e.,s. 98.

132 Ramazan Çalık, “Türk-Alman İlişkileri”, Türkler, Cilt: 16, Ankara 2002, s. 821.

133 Tarihe Düşülen Notlar-1, Yasama Yllı Açıllşlarında Cumhurbaşkanlarının Konuşmaları-1 (1 Mart 1924- 14 Aralık 1987), TBMM Yayinlar1, Ankara 2011, s. 118-119.

134 Ali Fuad Erden, İsmet İnönü, Ankara 1999, s. 228.

135 Aydemir, a.g.e. s. 265. 
yıpranması ve zayıflamasını amaçladığını belirtmiştir. ${ }^{136}$ Kahire Görüşmeleri’nde Eden, Sovyetlerin yayılmac1lığına dair hiçbir işaret olmadığını bir kere daha vurguladıktan sonra, "Eğer yayılmacı arzuları varsa bile Türkiye savaş dışında kalarak bunları değiştiremez" ${ }^{137}$ diyerek Türkiye'yi ikna etmeye çalışmış ancak Türkiye temkini elden bırakmamıştır. Anlaşılacağı üzere İngiltere, Türkiye'nin Sovyetlere güveni sağlandığı zaman, Müttefik Cephesinde savaşa gireceğine inanarak hareket etmiş ve bu nedenle de Türk-Sovyet ilişkilerinin düzelmesi konusunda çaba harcamıştır. ${ }^{138}$ Nitekim İngiliz hükümeti, Türkiye'nin İngiliz-Sovyet ilişkilerinde pürüz çıkarmasını istememekle birlikte, Rusya da Müttefik yardımlarıyla güçlenecek bir Türkiye'nin Kızıl Ordu'nun Balkanlar'a inişini engellemesinden endişe etmiştir. Türkiye ise Kızıl Ordu'nun 1944 sonbaharından itibaren Balkanlar'dan Türkiye'ye hızla inmesinden çekinmiştir. ${ }^{139}$

Bu bağlamda Türkiye büyük kuzey komşusu Sovyetler Birliği’yle ilişkilerinin daha önce yapılan antlaşmaların hükümleri içinde ve dostluk mahiyetinde olmasını ummaktadır. Sovyet Rusya'nın savaş sırasında sergilediği fedakârlık ve kahramanlığı bir nevi takdir eden Türkiye, savaş süresince imzaladığı antlaşmalara sadık kalarak ilişkilerini sürdürdüğü Sovyetlerle gelecekte devam edecek ilişkilerinin de dostluk ve komşuluk havası içerisinde geçmesini beklemektedir. ${ }^{140}$ Bu nedenle Türk hükümeti, Sovyetler Birliği ile ilişkilerinin düzeltilmesi yolunda Almanya'ya krom sevkiyatını durdurmuş, ardından Alman taraftarı olarak bilinen Dışişleri Bakanı Menemencioğlu'nun istifa ettiğini duyurmuştur. ${ }^{141}$ Daha sonra ise Türkiye, Sovyetler Birliği tarafından Almanya ile birlikte Pan-Türkist politika yapmakla suçlanmıştır. Bu durumda, gerginliği ortadan kaldırmak amaciyla hareket eden Türkiye, Mayıs 1944'te bir grup Türkçü yazar, akademisyen, öğretmen ve öğrenciyi "Irkçılık-Turancılık" yaptıkları iddiasıyla tutuklatmıştır. ${ }^{122}$ Dahası Sovyetlerle arasını açmak istemeyen Türkiye, Turancıları tutuklatmasının yanı sıra, kendisine sığınan Sovyet vatandaşlarını da ülkelerine iade etmiştir. Sovyetlere karşı iyi niyet gösterisine devam eden Türkiye, 1945 Ocak'ında savaş malzemesi taşıyan Sovyet gemilerinin Boğazlardan geçişine de izin vermiştir. Ancak bu iyi niyet gösterilerinden olumlu bir sonuç elde edemeyen Türkiye'nin Kızıl Ordu karşısındaki kuşku ve endişeleri daha da artmıştır. ${ }^{143}$ Böylece kuşku ve endişe içinde bulunan Türkiye, dış politikasında değişikliğe gitmek zorunda kalacaktır. Yani savaşın ilk yıllarından itibaren Almanya'ya karşı dengeleyici bir güç biçiminde ortaya çıkan Amerika'yı bu kez Sovyet tehdidine karşı bir güç olarak görmeye başlayacaktır. ${ }^{144}$

\section{3. İkinci Dünya Savaşı'nın Sona Ermesi ve Türkiye}

Savaş son dönemine yaklaşırken Sovyet çekincesini koruyan Türkiye, yanı başındaki coğrafya Balkanların Doğu Avrupa ile Yunanistan hariç Sovyet nüfuzu altına girmesinden endişe duymuştur. ${ }^{145}$ Nitekim Türkiye'nin Sovyetlerle ilişkilerini düzeltmek için yaptığı iyi niyet gösterileri de Sovyet kanadında tepkisiz kalmıştı. Üstelik 6 Eylül 1944'te Bulgaristan'1 işgal eden Sovyetlerin bu davranışı da Türkiye'yi endişeye sevk etmiştir. ${ }^{146}$ Savaşın

136 Koçak, Türkiye’de Milli Şef Dönemi (1938-1945), C. 2, s. 178.

137 Feridun Cemal Erkin, Türk-Sovyet Illişkileri ve Boğazlar Meselesi, Başnur Matbaası, Ankara, 1968, s. 205.

138 Akandere, a.g.e., s. 286.

139 Koçak, Türkiye’de Milli Şef Dönemi (1938-1945), C. 2, s. 269.

140 Tarihe Düşülen Notlar-1, Yasama Yılı Açılışlarında Cumhurbaşkanlarının Konuşmaları-1 (1 Mart 1924- 14 Aralık 1987), TBMM Yayınları, Ankara 2011, s. 118.

141 Koçak, Türkiye’de Milli Şef Dönemi (1938-1945), C. 2, s. 269-270.

142 Mahmut Goloğlu, Milli Şef Dönemi (1939-1945), Türkiye Cumhuriyeti Tarihi, Ankara 1974, s. 482.

143 Koçak, Türkiye'de Milli Şef Dönemi (1938-1945), C. 2, s. 270.

144 Avc1, a.g.m., s. 202.

145 Crampton, R. J., The Balkans Since the Second Worls War, Routledge, 2014. s. 5.

146 Ekinci, a.g.e., s. 669. 
aldığı durum üzerine Müttefiklerin 1944 Ekim'inden beri hazırlıklarını sürdürdüğü konferans Yalta'da 4-11 Şubat 1945 tarihinde toplanmıştır. ${ }^{147}$ Savaş sonrası kurulacak dünya düzeninin ilkelerini belirlemek amacıyla gerçekleştirilen bu zirvede, tartışılan konular ve ortaya çıkan sonuçlar, özellikle Türkiye'yi yakından ilgilendirecektir. Nitekim Stalin, zirvenin 10 Şubat 1945 günü yapılan yedinci oturumunda Boğazların ve Montreux Boğazlar Sözleşmesi'nin yeniden gözden geçirilmesini talep etmiştir. ${ }^{148}$ Stalin, Boğazlarla ilgili sözleşmenin, İngiltere ile Rusya'nın arasının iyi olmadığı bir dönemde yapıldığını söyleyerek, mezkûr sözleşmenin modasının geçtiğini öne sürmüştür. ${ }^{149}$ İngiltere ve ABD için Almanlara karşı onlarla aynı safta savaşmış ve zafer kazanmış bir ülke konumunda olan Sovyetlere karşılık, Türkiye savaş sırasında yürüttüğü politikalar ile yükümlülüklerini yerine getirmemiş ve savaşa girmemiş bir ülke konumundaydı. Bundan dolayı konferansta savaş sonrasında Boğazların statüsünün yeniden belirlenmesi şeklindeki Sovyet istekleri kabul edilmiştir. ${ }^{150}$ Ancak konu üzerine devam edecek görüşmeler, Londra'da yapılacak Dışişleri Bakanları toplantısına havale edilmiştir. ${ }^{151}$

Yalta Konferansı'ndan sonra İngiltere Büyükelçisi 20 Şubat 1945’te Türkiye'nin Birleşmiş Milletlere üye olabilmesi için 1 Mart 1945 tarihine kadar Mihver Devletlerine savaş açması gerektiğini bildirdi. ${ }^{152}$ Türkiye ise hem Sovyetler Birliği karşısında yalnız kalmamak hem de müttefikleri İngiltere ve Amerika ile ilişkilerini düzenlemek amacıyla 23 Şubat 1945 'te Almanya ve Japonya'ya savaş ilan etmiştir. ${ }^{153}$ Türkiye'nin harp ilanının Müttefik zaferi kesin mahiyet aldıktan sonra tesirsiz kabul edilmesi üzerine, ülkesi hakkında yapılan tenkitlere karşın İnönü, savaş süresince bitaraf politika güden Türkiye'nin bu siyasetinin Müttefik zaferine yardım ettiğini ve yine hem Almanya hem de Japonya'ya harp ilan etmesinin sadece Müttefiklerin isteği üzerine gerçekleştiğini belirtmektedir. İnönü, Müttefik zaferi kesin olduktan sonra harp ilân ettiği söylenen Türkiye'nin karanlık günlerde beraber olduğu Müttefiklerle, zafer günlerinde, ganimetten bir hisse almak dâvası gütmediğini dolayısıyla firsattan istifade gibi bir düşüncesinin asla bulunmadığını söylemektedir. Yine Türkiye, İkinci Dünya Savaşı’nda her türlü tehlikeleri göze alarak, açıktan açığa İngiltere'nin yanında ve Birleşmiş Milletler dâvasında kesin durum almıştır. Eğer Müttefikler için gelecek dünyada insanlık hislerinin temel alınması boş bir sözden ibaret değilse, Türkiye'nin, yeni dünya barışı için faydalı bir unsur olduğunun teslim olunacağına inanan İnönü, Türk topraklarından ve haklarından hiç kimseye verilecek bir borcu bulunmadığını, Türk milletinin şerefli insanlar olarak yaşayacağını ve şerefli insanlar olarak öleceğini öne çıkarmaktadır. ${ }^{154}$ Dolayısıyla İnönü bu son cümlesinden Sovyet Rusya'nın savaş sona yaklaşırken Türkiye'ye yönelik izlediği dış siyasetine gönderme yapmıştır. Böylece İnönü, Türkiye'ye yöneltilen eleştirilere net cevap vererek, savaşın muhtelif aşamalarında takip edilen dış siyaseti özetlemekle kalmamış, bu siyaseti meşruiyet zeminine oturtmuştur.

İnönü’nün yukarıdaki meclis yedinci dönem dördüncü yılı açış konuşması, İkinci Dünya Savaşı dönemi Türk dış politikasının tam olarak bir değerlendirilmesi biçimindedir. İzlenilen dış siyaset etrafında, Türkiye'nin sadece kendi bağımsızlığı değil, milletlerarası barış ve güvenlik davasında Müttefiklerin zaferine yönelik inancı da ön plana geçirilmiştir. İnönü'ye göre Türkiye, bütün gücü, kuvveti ve siyaseti ile Müttefik zaferine yardım ederken hiçbir karşılık beklememiş, askeri durum değiştikçe de alınan kararları daima müttefiki İngiltere ile ittifakla almış ve varılan kararlarda da Sovyetler Birliği'nin savunma ve güvenlik menfaatlerine zarar vermemek düşüncesinden ayrılmamıştır. Ancak savaşın sonuna doğru Türkiye'nin rolünün son bulduğu dönemde haksız hü-

147 Ülman, Haluk, Türk- Amerikan Diplomatik Münasebetleri (1939-1947), Ankara 1961, s. 50

148 Ekinci, a.g.e., s. 669.

149 Bilge, a.g.e., s. 261.

150 Ahmet Şükrü Esmer, Oral Sander, “İkinci Dünya Savaşında Türk Dış Politikası”, Olaylarla Türk Dış Politikasl (1919-1995), Siyasal Kitapevi, Ankara 1996, s. 182-183.

151 Gürün, a.g.e., s. 297.

152 Erkin, a.g.e.,s. 245.

153 Uçarol, a.g.e., s. 922-923.

154 Tarihe Düşülen Notlar-1, Yasama Yılı Açıllşlarında Cumhurbaşkanlarının Konuşmaları-1 (1 Mart 1924- 14 Aralık 1987), TBMM Yayınları, Ankara 2011, s. 123-124. 
cumlara uğradığını söyleyen Atay, sağduyu ve adalet duygularının bu söylentilere baskın geleceğine güvenmektedir. Nitekim Atay'a göre savaş bitinceye kadar demokrasi zaferine hizmet eden Türkiye'nin, savaş sonrasında da ancak hürriyet ve hak esaslarına dayanan bir barış düzeni kurulmasından ve gelecekte milletlerarası düzenin samimi bir dayanışma ile devam ettirilmesinden başka bir amacı yoktur. Yine Atay, Türkiye'nin barış düzeninin kurulması ve işlemesi döneminde başkalarının hak ve hürriyetlerine zarar verecek hiçbir şey vermeyeceğinin de altını çizerek 19 milyonluk Türk kitlesinin bu esaslar üzerinde fikir birliği içerisinde bulunduğunu aktarmaktadır. ${ }^{155}$ Anlaşılacağı üzere Atay, son cümlesiyle Sovyet Rusya'nın, Türkiye'nin bağımsızlığına ve toprak bütünlügüne zarar vermesine sesiz kalmayacağını dolayısıyla Türk toplumunun kitle halinde bir arada bulunacağını hem iç hem de diş kamuoyuna aktarmaktadır.

Ulus gazetesinde yazan Esat Tekeli, İnönü’nün dış politika konusunda bir müdafaa yapmaktan ziyade gerçekleri ortaya koyarak, Türkiye'nin hak ve adalet ideolojisini güden milletler arasında yer almaktan çekinmeden tam altı yıl devam eden savaş süresince her türlü baskı ve tehlikelere karşı saf değiştirmediğini belirtmektedir. Ayrıca İnönü'nün savaş sonunda Türkiye'nin demokrasi düşmanları arasında değil Müttefikler arasında yer alacağına yönelik açıklamasıyla, Türkiye'nin hukuki durumuna açıklık getirdiğini dile getiren Tekeli, böylece hukuki durumu ortada bulunan Türkiye'nin hakları ve toprakları üzerinde bir mesele açıldığında milletlerarası hukuk ile birlikte Atlantik prensipleri ve milletlerarası anayasa esaslarının boş sözlerden ibaret olmaması gerektiğini özellikle dünya kamuoyuna aktarmıştır. ${ }^{156}$

Akşam'da yazan Sadak da, savaşta tuttuğu yol ve sürdürdüğü siyaset hakkında Türkiye'ye söz söyleyenlere ve dünü bahane ederek Türkiye'nin bugünkü siyasetine dil uzatanlara karşın, İnönü'nün söylediği nutukla, altı yıllık savaş içindeki Türkiye'nin sürdürdüğü siyasetin açık hesabını verdiğini, demokrasi ve hürriyet alanında ise gidilecek yolu esası bir şekilde anlattığını aktarmaktadır. ${ }^{157}$

Tan gazetesinde yazan Sertel ise gizli hiçbir emeli bulunmayan Türkiye'nin Cumhurbaşkanı İnönü'nün dünya kamuoyu önünde vicdan huzuruyla konuşabilmesini önemseyerek, Türkiye'yi eleştirenlerin Türkiye'den toprak ve çeşitli hak talebinde bulunmalarına yine İnönü’nün sözleriyle cevap vermektedir: “Türk topraklarından ve haklarından hiç kimseye verilecek bir borcumuz yoktur. Şerefli insanlar olarak yaşayacağız ve şerefli insanlar olarak öleceğiz.”158

Nitekim Türkiye'nin Mihver Devletlerine savaş ilanının ardı sıra, savaş meydanlarında kazandığı zaferlerin meyvesini elde etmek isteyen Sovyet Rusya 19 Mart 1945 tarihinde, 17 Aralık 1925 tarihli Türk Sovyet Dostluk ve Tarafsızlık Antlaşması'nın fesih ettiğini bildirmiştir. ${ }^{159}$ Sovyetlerin davranışını, değerlendiren Erkin: “Türkiye'nin Birleşmiş Milletlere katılması sonucunda elde ettiği yararları hiçe indirmek ve bu katılma neticesinde sağladığı uluslararası istikrarı San Francisco Konferansı'ndan önce kaybettirmek"160 kanaatine ulaşmıştır. Gerçekten de Türkiye savaşın son anında Mihver Devletlerine savaş ilan etmesi ile asli üyeleri arasına girmeyi bir hak olarak kazandığı Birleşmiş Milletler Teşkilatı'nın kurulması amacıyla 25 Nisan 1945'te toplanan San Francisco Konferansı'nda, yalnızlığını belirli bir biçimde hissetmiştir. ${ }^{161}$

İnönü, Türkiye'nin dış siyasetini özetlediği meclisin yedinci dönem dördüncü yılı açış konuşmasında, Sovyetlerin 1925 Dostluk Antlaşması'nın feshi üzerine, yeni esaslarda ve ciddi olarak iyileştirilmiş bir antlaşma yapmak için Türkiye'nin bütün gayretini sarf ettiğini ancak herhangi olumlu bir neticede elde edilmediğini

155 Falih Rıfkı Atay, “Devlet Başkanının Nutku”, Ulus, 2 Kasım 1945, s. 1, 3.

156 Esat Tekeli, “Dünya Önünde Bir Muhasebe”, Ulus, 4 Kasım 1945, s. 1-2.

157 Necmeddin Sadak, “Türkiye’nin Dünü, Bugünü ve Yarını”, Akşam, 2 Kasım 1945, s. 1.

158 M. Zekeriya Sertel, “Türkiye’yi Kimler ve Niçin İtham Ediyorlar?”, Tan, 3 Kasım 1945, s. 1.

159 Bilge, a.g.e., s. 265.

160 Erkin, a.g.e., s. 249-250.

161 Goloğlu, a.g.e., s. 483. 
aktarmaktadır. Ancak Türkiye'nin iyi niyetli dış siyasetinin daha iyi anlaşılacağından, iyi komşuluk hislerinin öne çıkarak, iki memleket arasında iyi münasebetler kurulması ihtimalinden ümidini kesmediğini belirten İnönü, İngiltere'ye ittifak münasebeti ile bağlı bulunan Türkiye'nin, Amerika Birleşik Devletleri ile münasebetlerinin de artan bir dostluk içinde geliştiğini söylemektedir. Yine İnönü, Sovyet Rusya dışında coğrafyasında yer alan diğer ülkelerle de dostluk ilişkisi güden Türkiye'nin medeni bir millet ve devlet olarak insanlık ailesinin çalışkan ve faydalı bir uzvu olmaktan başka bir siyasi hedefinin bulunmadığının altını çizmiştir. ${ }^{162}$

Müttefiklerin Potsdam Konferansı'ndan önce Türkiye’ye verdiği notalar doğrultusunda Boğazlarda ve Doğu Anadolu'da bir takım istekleri bulunan Sovyet Rusya pazarlık gücünü artırmak niyetiyle hareket ederken, müttefiki İngiltere'nin de tepkisini çekmiştir. Uzak Doğu'da devam eden savaşa odaklanan ABD ise başlangıçta Sovyetleri karşısına almak istemeyecektir. ${ }^{163}$ Sovyet istekleri 17 Temmuz-2 Ağustos 1945 tarihleri arasında Müttefiklerin Potsdam Konferansı'nda bir kez daha gündeme geldi. Sovyetler Türkiye'ye yönelik taleplerini yine konferansta dile getirmiştir. Sovyetlerin isteklerine ulaşmak için baskı ve tehdit yöntemini kullanmaları ise Türkiye'yi Batıya yakınlaştırmıştır. ${ }^{164}$ Potsdam'da Türkiye ile alakalı çıkan karar, Montreux Boğazlar Sözleşmesi'nin ne şekilde değiştirileceğine dair konunun Dışişleri Bakanları toplantısında ele alınacağına yöneliktir. Mezkûr toplantıda yer alacak üç devletin bu konuda görüşlerini Türkiye'ye bildirmelerine karar verilmiştir. ${ }^{165}$

Potsdam Konferans1'ndan sonra İngiltere ve ABD'nin, Sovyetlerin, kendi hak ve egemenliğine yönelik taleplerine karşı takındıkları tavırda yalnız kalan Türkiye savaşa girilmemesi üzerine kurulu dış politikanın sonunun geldiğinin farkına varacaktır. Böylece Sovyetler verdikleri notalarla Türkiye üzerindeki baskılarını artırırken Türkiye ise içine düştüğü yalnızlıktan kurtulmak, İngiltere ve ABD’nin desteğini kazanmak için çaba sarf edecektir. ${ }^{166}$

Nitekim savaşın özellikle son aylarında Sovyetler Birliği'nin dünyadaki saygınlı̆̆ının artmasının yanında Doğu Avrupa'da etkinliğini arttırması önce İngiltere'yi daha sonra da ABD'yi de kuşkuya sevk etmiştir. Batı ülkelerinin Sovyetler Birliği'ne karşı mevcut kuşkuları, savaş sonunda yalnız kalan Türkiye'yi Batı ülkelerine yaklaştıracaktır. Nitekim bir süre bocalama devrinden sonra Türkiye, daha belirgin bir biçimde dünya dengelerinin oluşturduğu kamplardan biri konumundaki Batı kampına giderek yaklaşacaktır. ${ }^{167}$

\section{Sonuç}

İkinci Dünya Savaşı esnasında gerek Cumhurbaşkanı İsmet İnönü’nün mecliste yaptığı konuşmalar gerekse de bu konuşmalarla alakalı dönemin basınında yazılan makale ve haberlerde ileri sürülen argümanlar Türkiye'nin savaş sürecinde takip ettiği politikalarla ilgili veriler sunmaktadır. $\mathrm{Bu}$ veriler üzerinde genel bir değerlendirme yapılacak olduğunda ilk önce itidalli davranış ve tarafsızlık politikasının söylem ve yorumlarda baskın bir biçimde kendini belli ettiği görülmektedir. Diğer yandan da söylemler tematik kodlandığında 'temenni', 'tarafsızlık', 'katkı' ve 'bütünlük' şeklinde sınıflandırılabilir durmaktadır.

162 Tarihe Düşülen Notlar-1, Yasama Yılı Açıllşslarında Cumhurbaşkanlarının Konuşmaları-1 (1 Mart 1924- 14 Arallk 1987), TBMM Yayınları, Ankara 2011, s. 124.

163 Türkiye Cumhuriyeti Dışişleri Bakanlı̆̆ı Araştırma ve Siyaset Planlama Genel Müdürlüğü, İkinci Dünya Savaşı Ylları 1939-1946, C. V, s. 268-270; Bilge, s. 265-279.

164 Erel Tellal, "SSCB’yle İlişkiler”, Türk Dış Politikası, C. 1, Editör: Baskın Oran, İletişim, İstanbul 2014, s. $502-508$.

165 Gürün, a.g.e., s. 297-298.

166 Ayın Tarihi, 12 Mart 1947.

167 Deringil, a.g.e., s. 276. 
Temenni 1939 yılındaki konuşmasında belirmektedir. Konuşmada amaçlarının savaşın ilerlemesine engellemek olduğu ve harbin son bulmasının umut edildiği dile getirilmekte basında da benzer yansimalar yer almaktadir.

Tarafsızlık içerikli söylemler ise 1940-1942 yıllarında net olarak belirginleşmektedir. Taraflarla yapılan ittifaklarla bu sağlanmaya çalışılmış, söylemler bu ittifaklar üzerinden yapılmıştır. Bu ittifakların basına yansımasına baktığımızda gerek Sadak gerek Sertel gerekse de Atay’ın destekler mahiyette yazıları ön plana çıkmaktadır. İttifaklarla Avrupa'da emniyet mıknatısı sağlandığı işlenmekte ve halkın rahatladığı üzerinde durulmaktadır. İlaveten ittifaklarla ilgili dış basınsa referans yapılarak oralarda yer alan olumlu değerlendirmeler kamuoyuna sunulmaktadır. Almanya'nın Fransa'ya saldırması ardı sıra İtalya'nın da savaşa dâhil olmasıyla cephenin Balkanlara yayılması, savaşı Türkiye'nin yanına taşımıştır. Dolayısıyla tarafsız kalmak gittikçe güçleşmiştir. Nitekim İnönü de gittikçe aratan düşmanlıklar içerisinde tarafsız kalmanın yoruculuğunu dillendirmektedir. Ardından da Türkiye'nin hileli ve saklı politika izlemediği aktarılarak şeffaflığı vurgulanmaktadır.

1943 yılına geldiğimizde meclis açılış konuşmasında ise Türkiye'nin savaş dışında kalmasına rağmen savaşın zararlı etkilerini hissettiği belirtilmektedir. Bu söylemin o dönem gündeme gelen müttefik isteklerine karşı kullanılacak bir manevra alanı açmak için kullanıldı̆̆ı anlaşılabilmektedir.

Söylemlerde katkı unsurlarının belirginleştiği dönem ise Almanya'nın Stalingrad'da yenilerek Kuzey Afrika'dan çekilmesiyle, dengelerin değiştiği döneme denk gelmektedir. Müttefikler savaşta avantajlı konuma geçmiştir. Bu süreçteki söylemlerde Türkiye'nin izlediği politikanın esasında Müttefiklerin lehine olduğu işlenmektedir. Bu dönemde basında da Müttefiklere görece daha açıktan destek göze batmaktadır. Sertel'in bu hususta Almanya'yı dünya hâkimiyeti kurmak için, diğer taraftan Müttefiklerin ise hürriyet, adalet ve insanlığın refahı için savaştığını beyan eden yazıları örnek gösterilebilir.

Bütünlük olarak ifade edilen söylemler ise dünyanın yeniden şekillendiği konferanslar dönemine denk gelmektedir. Özellikle Sovyet Rusya'nın Boğazlar üzerinden istekleri İngiltere'nin ilk dönem kayıtsızlı̆̆ı, siyasileri, ülke bütünlüğünü muhafazası için her yolun kullanılacağı yönlü söylemler üretmeye yönlendirmiştir. Basında da bu konular işlenirken toprak bütünlüğü vurgulanmakla birlikte Boğazlar özelinden Sovyet Rusya'yı daha alttan alan bir dilin hâkimiyeti göze çarpmaktadır.

K1saca İkinci Dünya Savaşı sürecinde İsmet İnönü’nün 1 Kasım tarihlerinde meclis açılışında yaptığı konuşmalar Türkiye'nin mezkûr süreçte takip ettiği politikaları yansıtmaktadır. Dönemin Türk basınının da bu politikalar doğrultusunda yayınlar yaptığı belirgin durmaktadır.

\section{Kaynakça}

Akandere, Osman, Milli Şef Dönemi, İz Yayıncılık, İstanbul 1998.

Armaoğlu, Fahir, 20. Yüzyıl Siyasi Tarihi 1914-1995, Timaş, İstanbul 2006.

Atay, Falih Rifk1, “Cumhurreisimizin Nutku”, Ulus, 2 Kasim 1939, s. 2.

Atay, Falih Rifk1, “Devlet Reisimizin Nutku”, Ulus,1 Kasım 1942, s. 1, 3.

Atay, Falih Rifk1, "Cumhurreisimizin Nutku”, 2 Kasim 1943, Ulus, s. 1, 3.

Atay, Falih Rıfkı, Devlet Reisimizin Nutku”, Ulus, 2 Kasım 1944, s. 1. 
Atay, Falih Rıfkı, "Devlet Başkanının Nutku”, Ulus, 2 Kasım 1945, s. 1, 3.

Atay, Falih Rıfk1, Nutuk Bir Vazifeler Düsturudur, Ulus, 4 Kasım 1941, s.1.

Avc1, Ayşegül, "Winning the war of perception: american attempts to counter Germany's military influence in Turkey during World War II", Turkish Studies, Vol. 17, No. 1, 2016, ss. 202-219.

Aydemir, Şevket Süreyya, II. Adam, C. II, Remzi Kitabevi, İstanbul 2005.

Aydın, Mustafa, “İkinci Dünya Savaşı ve Türkiye, 1939-1945”, Türk Dış Politikası, C.1, Editör: Baskın Oran, İletişim, İstanbul 2014, ss. 399-479.

Ayın Tarihi, 12 Mart 1947.

Belge, Burhan, “Türkiye’de Bir Şef Yaşar”, Tan, 2 Kasım 1942, s. 1-2.

Biagini, Antonello, Çăgdaş Türkiye Tarihi, Phoenix, Ankara 2007.

Bilge, Suat, Türkiye-Sovyetler Birliği İlişkileri 1920-1964: Güç Komşuluk, Türkiye İş Bankası Kültür Yayınları, Ankara 1992.

Bilsel, Cemil, Lozan, Sosyal Yayınlar, İstanbul 1998.

Bowen, Wayne, “Türkiye ve İkinci Dünya Savaş1: “Taraflı Fakat Savaşmayan Ülke”, Türkler, Edt: Hasan Celal Güzel, Kemal Çiçek, Salim Koca, Yeni Türkiye Yayınları, Ankara 2014, ss. 803-812.

Çakmak, Cenap, “Turkey In The Second World War: "Evasive” Or “Active” Neutral?", Akademik Araştırmalar Dergisi, S. 26, 2005, ss. 61-78.

Çalık, Ramazan, “Türk-Alman İlişkileri”, Türkler, Cilt: 16, Ankara 2002.

Deringil, Selim, Denge Oyunu, Tarih Vakfı Yurt Yayınları, İstanbul 2014.

Ekinci, Necdet, Inönü Dönemi ve II. Dünya Savaşı Yılları, Genel Türk Tarihi, Ankara 2002.

Erden, Ali Fuad, İsmet İnönü, Ankara 1999.

Erdoğan, Caner, “Tek Parti Dönemi’nde Cumhuriyet Halk Partisinin İdeolojik Değişim ve Dönüşüm Sürecinin Çözümlenmesi”, Uluslararası Sosyal Araştırmalar Dergisi, Say1:51, Ağustos 2017, ss.270-279.

Erkin, Feridun Cemal, Türk-Sovyet İlişkileri ve Boğazlar Meselesi, Başnur Matbaası, Ankara, 1968.

Esmer, Ahmet Şükrü, Sander, Oral, “İkinci Dünya Savaşında Türk Dış Politikası”, Olaylarla Türk Dış Politikası (1919-1945),Siyasal Kitabevi, Ankara 1996.

Goloğlu, Mahmut, Milli ŞefDönemi (1939-1945), Türkiye Cumhuriyeti Tarihi, Ankara 1974.

Gönlübol Mehmet- Sar, Cem, “1919- 1939 Dönemi”, Olaylarla Türk Dış Politikası, Siyasal Kitabevi, Ankara 1996.

Gönlübol Mehmet- Sar, Cem, Atatürk ve Türkiye’nin Dış Politikası (1919-1938), Atatürk Araştırma Merkezi Yayınları, Ankara 2013.

Gürbüz, Kahraman, “İkinci Dünya Savaşı'nda Balkanlardaki Gelişmeler ve Türkiye'nin Tutumu”, U.Ü.Fen-Edebiyat Fakültesi Sosyal Bilimler Dergisi, sayı:18, 2007/2, ss.363- 
372.

Gürün, Kamuran, Türk-Sovyet İlişkileri (1920-1953), TTK Yayınları, Ankara 1991.

Hale, William, Türk Dış Politikası, 1774-2000, Arkeoloji ve Sanat Yayınları, İstanbul 2003.

Haluk, Ülman, Türk- Amerikan Diplomatik Münasebetleri ( 1939-1947), Ankara 1961.

İlyas, Ahmet, Turan, Orhan, İnönü Dönemi Türk D1ş Politikası, Atatürk İlkeleri ve İnkllap Tarihi Enstitüsü Atatürk Dergisi, 20121 (1), ss.319-341.

Koçak, Cemil, Türkiye'de Milli Şef Dönemi (1938-1945), C.2, İletişim Yayınları, İstanbul 2010.

Koçak, Cemil, Türkiye'de Milli Şef Dönemi (1938-1945), C. 1, İletişim Yayınları, İstanbul, 2015.

Mutlu, Sevda, Devlet Adamı Kimliği İle İsmet İnönü’nün Düşünce ve Uygulamalarının Değerlendirilmesi, (Basılmamış Doktora Tezi), Cumhuriyet Üniversitesi Sosyal Bilimler Enstitüsü, Sivas 2007.

Oran, Baskın, “1939-1945: Savaş Kaosunda Türkiye: Göreli Özerklik-2”, Türk Dış Politikası, C.1, Editör: Baskın Oran, İletişim, İstanbul 2014.

Özden, Hakan, “The Diplomatic Maneuvers of Turkey in World War II”, Karadeniz Araştırmaları, Bahar 2013, S. 37, ss. 92-110.

Parker, R.A.C., II. Dünya Savaşı, Dost Kitabevi, Ankara 2005.

R. J., Crampton, The Balkans Since the Second Worls War, Routledge, 2014.

Sadak, Necmeddin, “Cumhurreisimizin Nutkunda Türkiye'nin Dış Politikası”, Akşam, 3 Kasim 1942, s. 1-2.

Sadak, Necmeddin, “Bütün Millet, Kahraman Şefine: "Seninle Beraberiz!” diyor”, Akşam, 3 Kasim 1940, s.1.

Sadak, Necmeddin, "Devlet Reisinin nutku: Dış siyasetimiz”, Akşam, 4 Kasım 1944, s.1.

Sadak, Necmeddin, "Emniyet Havası İçinde İnsanlara Temiz Nefes Aldıracak Bir Adalet Nizamı İstiyoruz”, Akşam, 2 Kasım 1943, s. 1.

Sadak, Necmeddin, "Reisicümhurun Nutku”, Akşam, 2 Aralık 1939, s. 1, 8.

Sadak, Necmeddin, “Türkiye’nin Dünü, Bugünü ve Yarını”, Akşam, 2 Kasım 1945, s. 1.

Sertel, M. Zekeriya “İtalya-Yunan Harbi Önünde Türkiye’nin Vaziyeti”, Tan, ,4 Kasım 1940, s. 1-2.

Sertel, M. Zekeriya, “Dünya Siyasetinde Türkiye'nin Vaziyeti”, Tan, 3 Kasım 1939, s.1, 6.

Sertel, M. Zekeriya, "Milli Şefimizin Dış Siyasetimize Ait Yeni Direktifleri”, Tan, 2 Kasim 1943, s. 1.

Sertel, M. Zekeriya, "Milli Şefin Dış Siyasetimiz Hakkındaki Beyanatı”, Tan, 3 Kasım 1941, s. 1

Sertel, M. Zekeriya, “Türkiye’yi Kimler ve Niçin İtham Ediyorlar?”, Tan, 3 Kasım 1945, s. 1.

Seydi, Süleyman, “1939-1945 Dönemi İç ve Dış Politika”, Ed: Adem Çaylak vd., 
Osmanlı'dan İkibinli Yıllara Türkiye'nin Politik Tarihi, Savaş Yayınevi, Ankara.

Soysal, İsmail, Türkiye'nin Siyasal Andlaşmaları, TTK Yayınları, Ankara 2000.

Soysal, İsmail, Türk Dış Politikası İncelemeleri İçin Kılavuz, İstanbul 1993.

Tarihe Düşülen Notlar-1, Yasama Yılı Açıllşslarında Cumhurbaşkanlarının Konuşmaları-1 (1 Mart 1924- 14 Aralık 1987), TBMM Yayınları, Ankara 2011.

Tekeli, Esat, "Dünya Önünde Bir Muhasebe”, Ulus, 4 Kasım 1945, s. 1-2.

Tellal, Erel, "SSCB’yle İlişkiler”, Türk Dış Politikası, C. 1, Editör: Baskın Oran, İletişim, İstanbul 2014.

Turan Refik ve Diğerleri, Atatürk Illkeleri ve İnklap Tarihi, Okutman Yayıncılık, Ankara 2009.

İkinci Dünya Savaşı Yıları 1939-1946, Türkiye Cumhuriyeti Dışişleri Bakanlığı Araştırma ve Siyaset Planlama Genel Müdürlüğ̈̈, C. V.

Uçarol, Rifat, Siyasi Tarih (1789-2014), Der Yayınları, İstanbul 2015.

VanderLippe, John M., Politics of Turkish Democracy: Ismet Inönü and Formation of the Multi-Party System 1938-1950, State of New York Press, USA 2005.

Weisband, Edward, İkinci Dünya Savaşında İnönüınün Dış Politikası II, Çev: M. Ali Kayabal, Cumhuriyet Yayınları, İstanbul 2000.

Weisband, Edward, İkinci Dünya Savaşı'nda İnönü’nün Dış Politikası I, Çev: M. Ali Kayabal, Cumhuriyet Yayınları, İstanbul 2000.

Yılmaz, Mustafa, “İnönü Dönemi Türk Dış Politikası”, Selçuk Üniversitesi Atatürk İlkeleri ve Inkilap Tarihi Araştırma ve Uygulama Merkezi Dergisi, Say1: 8, Konya 1999.

Zürcher, Erick Jan, Modernleşen Türkiye'nin Tarihi, (Çev: Yasemin Saner Gönen), İletişim Yayınları, İstanbul 2007. 